UM Libraries Depository

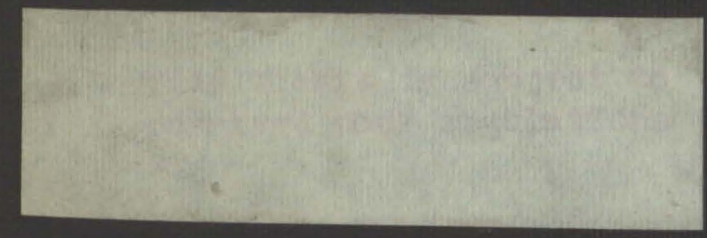



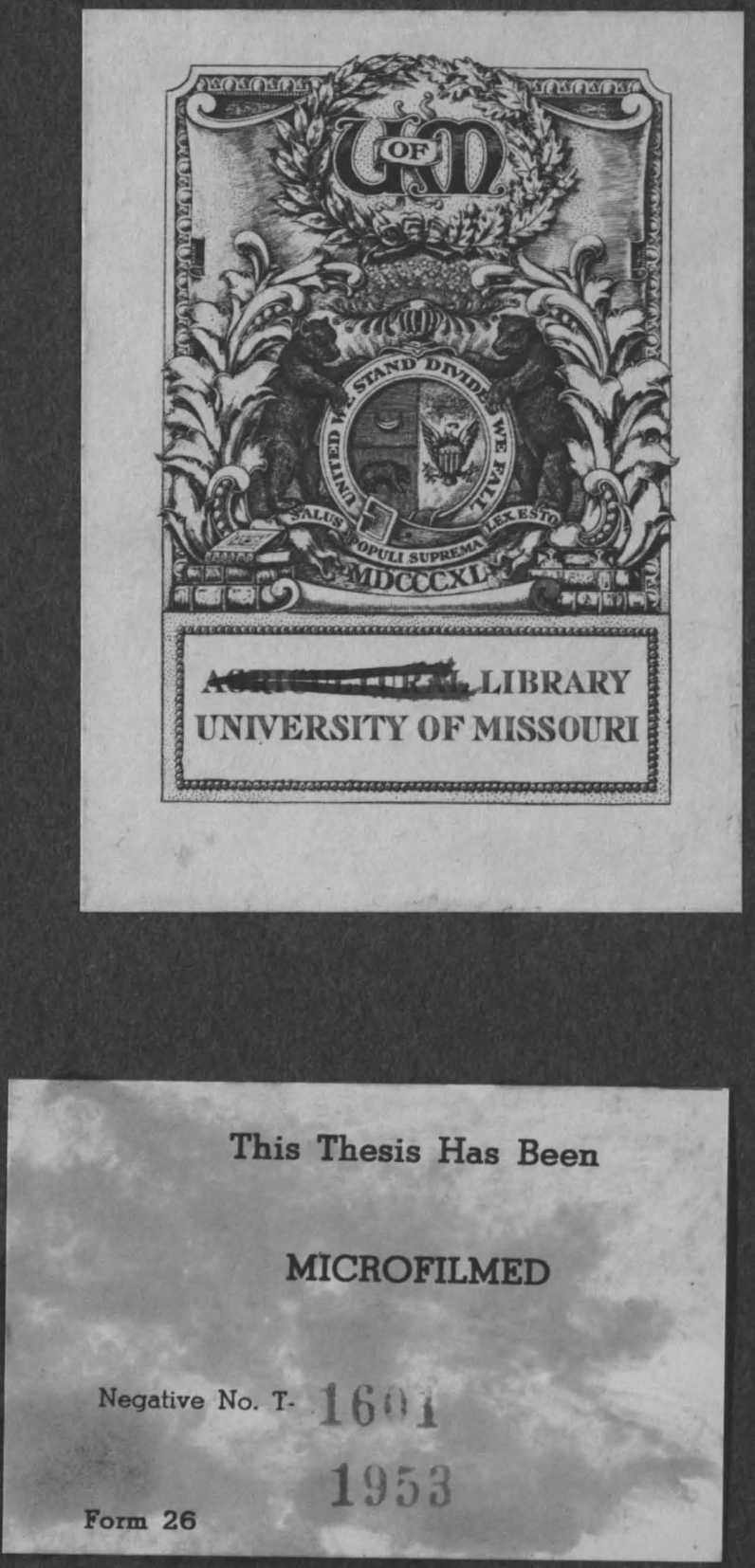






\section{AN INVESTIGATION}

\section{OF THE}

REST PERIOD OF SEEDS

by

Cleo Claude Wiggans B. S. in Agr.

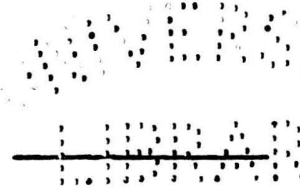

$\therefore \because \cdots$

$\because: \because \because \vdots$

Submitted in Partial Fulfillment of the

Requirements for the Degree of

Master of Arts

in the

GRADUATE SCHOOI

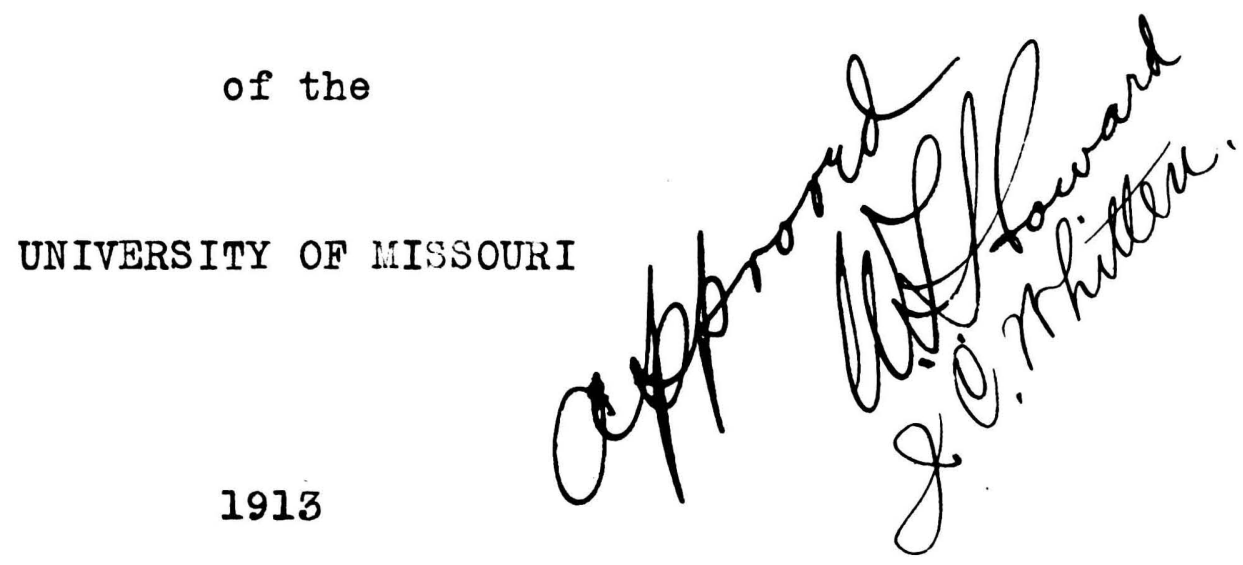



AN INVESTIGATION OF THE REST PERIOD OF SEEDS.

INTRODUCTION .

"All life is rhythmic in character, each life cycle being a repetition of a preceding one, and during the progress of the "grand period" of each individual various periodic movements occur in growing and adult organs."

In all plants, including fungi and algae, as well as higher forms, this periodicity of growth, due to season, nutrition, environment, etc., is seen. Practically all temperate zone plants exhibit a yearly periodicity. The change in. season causes a period of activity in summer and a corresponding one of rest in winter. Seeds also show this same phenomenon of periodicity of growth.

The fact that nearly all plants exhibit a periodical rest period, during which - under normal conditions - there is no growth, has long been known, and the general problem of discovering the causes and factors influencing this dormant

IPfeffer, Plant Physiology Vol. II p. 197. 

period has interested investigators for many years. However, it is only within the last few years that any definite knowledge has been secured in answer to some of the many interesting questions arising from a consideration of this fundamental plant-growth problem. Much work must still be done before the final explanation of some of the phenomena accompanying the dormant period can be satisfactorily made.

The following report, dealing with an investigation of the rest period of seeds, is only one specific part of a problem dealing with the rest period of plants in general. Work upon this broader problem was begun several years ago by Dr. W. L. Howard of the Missouri Experiment station, and the present work has been carried out largely under his direction. Much help and many useful suggestions have come from him in connection with the present investigation.

OB JECTS OF THIS INVESTIGATION.

The objects of this investigation were two in number. The first one was to answer the question: 'Do seeds have a natural rest period and, if so, in which species is it the most pronounced?' The answer to this question might also answer the question: 'Why are certain plants found growing only in certain seasons of the year?' To accomplish this object seeds were gathered and planted as soon as mature. Others were allowed to become thoroughly dry before planting so that all ripening processer were completed before the seeds were placed under normal growing conditions. Also a few were gathered before 

quite mature and planted immediately.

A second object was to determine the effect of various treatments such as etherization, freezing, and soaking, or a combination of these, on hastening the process and increasing the percentage of germination. This really resolves itself into the question: 'Can the rest period of seeds be broken, and if so, what agencies stimulate them into growth?'

\section{GENERAL STATEMENT .}

The present work, however, does not attempt to cover all phases of seed germination but rather restricts itself to that portion of the problem, the results of which can be made to compare directly with the previously mentioned work on the "Rest Period of Plants".2 For that reason the work was confined to only certain phases of the general problem. No consideration was given to the subsequent growth of the seedings, the only concern being the ability of the seed to germinate and the length of time between planting and the beginning of growth.

While any form of treatment to hasten the germination of seeds probably has more scientific than practical value, yet there are some seeds which lose their germinating capacity very quickly and, if the percentage of germination could be materialIy increased at a small expense, such treatment would be worthy of practical application.

2Howard, Mo. Exp. Sta. Research Bul. I. 

It has often been noticed that some seeds germinate much more quickly than others under the same conditions. Pfeffer3 in speaking of the periodicity of growth in seeds, sums up as follows: "Certain seeds are capable of immediate germination, whereas others must first rest for a few weeks, months, or years, even when they are not dry but are kept under conditions favorable for germination.

"Thus the seeds of Trapa natans and probably of most other aquatic plants whose seeds sink to the bottom when ripe, germinate the following spring. Wiesner found that seeds of the mistletoe, and Kientz that those of the white fir, pine, beech, hornbeam and ash, germinate the following year, and only very exceptionally the same year. Of sowings of ripe seeds of Cuscuta, Euphorbia cyparissias, etc., a number germinate very soon, but others not until the following year, and in the case of Euphorbia exigena, some not until after nine years."

Pfeffert further states that this delay of germination is due only in part to the relative impermeability of the seed coat for evidently some internal change is occurring in those seeds which swell up but still do not germinate. Growth may be entirely or only partially suspended during the dormant phase. An example of this appears in the seeds of Eranthis hiemalis, Ranunculus Ficaria and other plants. These seods have only small embryos when shed, but the embryos gradually

\footnotetext{
3Pfeffer, Plant Physiology Vol. II p. 207

${ }^{4}$ Pfeffer, Plant Physiology Vol. II p. 208
} 

enlarge at the expense of the endosperm. The length of the dormant period may be affected by previous cultural conditions but the conditions which lead to oertain seed resting under the soll for as long as fifty years and germinating when dug up have not yet been determined.

In a discussion of this subject Jost 5 raises several questions, some of which are: "Is this state of 'rest' real and absolute or only apparent? Is the quiescence of the dry seed really due not to the abolition of vital processes but only to the diminution of these to such an extent that they cannot be realized? Does respiration, a vital process, cease or only greatly diminish?" etc.

Bolkwitz (1901) showed that the amount of $\mathrm{CO}_{2}$ given off by seods decreases very rapidly as the percentage of water decreases, and in air dry seeds it reaches a value which is practically zero since only $1 \%$ of the dry weight of the seeds would be respired in one hundred years. From this work the conclusion may be drawn that respiration is not essential to the continuance of a vital capacity since many seeds are not Injured, so far as their germinating capacity is concerned, by enduring a deslccation so thorough that respiration would have no physiological significance. Schroeder (1886) germinated barley containing only $2 \%$ moisture but an interval of eleven to twelve weeks elapsed before germination. Although a change in the proteids of the seed, tending to make them insoluble, probably occurs, yet it is out of the question to suppose that

5Jost, Plant Physiology pp. 34t -345 . 

the death of the resting seed is due to the using up of all the reserve substances in the respiratory process.

Many seeds are unable to germinate immediately after reaching maturity and they show the power of development only after a certain period of hibernation. It is definitely known that the variations in the germination of certain seeds depend upon the varying degrees of the permeability of the seed coat to water but we know nothing farther as to why those which have imbibed water are kept from germinating. Undoubtedly internal factors play a most important part in determining the initiation and cessation of the resting period in seeds.

\section{HISTOR IC AL.}

Previous work along the line of hastening or increasing the germination of seeds has been quite extensive and many methods of stimulation, mechanical as well as chemical, etc., have been tried with varying success. A brief review of some of this work is given.

Mechanical Stimulation---It is a well known fact that many seeds have such a hard seed coat when they become dry that It is almost impossible for the young plant to force its way out through this hard covering. To overcome this difficulty seeds with a hard stony covering are sometimes cracked open before planting. In other cases a hole may be bored through the testa so that the entrance of moisture may be greatly hastened. Other

\footnotetext{
6Jost, Plant Physiology p. 342

7 Jost, Plant Physiology p. 342
} 

methods such as pricking with a needle, burning with a hot wire, etc., have been devised and in many cases satisfactory results were secured.

Perhaps the leguminous plants are more conspicuous than any other group in pessessing what are termed "hard" seeds. These are seeds which do not germinate readily and, because of this fact, breeding work with such plants, especially red clover has often been seriously hindered. Wllliams in speaking of this breeding work at the Ohio Agricultural College is credited with the following statement: "Some samples show 80-90\% germination and others only 5-10\%. I feel reasonably safe in saying that fully three-fourths of our plants show $20 \%$ germination or below."

Obviously any method that will increase the germination of clover seed or any other seed exhibiting the same peculiarities would have a distinct economic as well as scientific value. Williams solved this problem in a way by shaking the seed in a box Iined with sand paper. After such treatment better germination was secured but such a method would necessarlly have only a limited value.

\section{9}

Crocker (1907) did some work with the germination of seeds of aquatic plants. Seeds collected wile still green germinated quite readily but in many instances the dried seed refused to germinate. However, this difficulty was overcome by

8Cornell, Experiment Station Bulletin 312 p. 296

90rocker, Botanical Gazette 44:375-380 

cracking the seed coat. Such treatment gave prompt growth and a high percentage of germination. The results are accounted for on the theory that the delay and even failure in the germinating process was due to the inability of water to penetrate the seed coat rather than to any specific embryo characters.

A direct wounding of the seed itself may somtimes stimulate accelerated germination. 10

While freezing and stratification may in some instances be mechanical in nature yet other effects also are very probably secured from such treatment. Nevertheless, it is generally known that some seeds seemingly must undergo freezing before they will germinate.

Chemical stimulation---Various chemical or enzymic solutions have been used by different scientists to hasten or retard germination but the use of sulphuric acid is probably the most common treatment. Restrup (1898) used sulphuric acid on a sample of Lathyrus sylvestris and secured $100 \%$ germination as compared with $76 \%$ in the untreated lot. Treated "flat pea" seed also gave a much greater percentage of germination than the untreated ones.

Todaro $^{12}$ (1901), working independently, had also found that sulfurio acid (sp. $g r .1 .84$ ) acted upon the hard seeds of

10Experiment Station Kecord Vol. 22 p. 326

11 Experiment Station Kecord 10:53-4

12Experiment Station Record 13:754-5 

many leguminous plants rendering them capable of prompt germinetion. The treatment consisted of immersion in the acid for one hour at a temperature of $25-28^{\circ} \mathrm{C}$. In addition to hastenIng the growth a greater total germination was also secured in some cases.

Thornber ${ }^{13}$ treated seeds of several species with sulfuric acid in which chromic acid had been dissolved and then neutralized with potassium hydrate. Seeds of acacia, mesquite, Iocust and others germinated quite readily. In the case of extremely molsture resistant seeds it was found that treating with hot water $\left(85^{\circ}-88^{\circ} \mathrm{C}.\right)$ for 2-6 minutes accelerated germination.

Schneider-Orelli ${ }^{14}$ used the sulfuric acid treatment for refractory seeds and increased the percentage of germination from $15 \%$ to over $75 \%$.

Love and Leighty ${ }^{15}$ carried on experiments regarding the effects of concentrated sulfuric acid upon seeds of red clover, white clover, alfalfa and cotton. Their data show that increased germination was secured and also that some of the obnoxious weed seeds were destroyed. Contrary to an opinion previously expressed by Todaro they found that the effects of the acid treatment were apparent even after the seeds were allowed to dry before germination.

13Thornber, Ariz. Station Report 1904 p. 489-93

14Experiment Station Record 24:231

15Love \& Leighty, Cornell Exp. Station Bulletin 312 

Old seed often germinated more quickly and a higher percentage was also secured after the acid treatment. However, seeds with thin seed coats may be injured by such treatment.

Organic acids have also been found to increase and accelerate the growth process in seeds. Such treatment has been held to contribute to the nutrition of the growing embryo. 18

Stone and Smith (1895) made a series of tests to determine to what degrees seeds could be stimulated into germinating by subjecting them to various enzymic solutions. The solutions used were those commonly found in seeds and seedlings. It was thought that possibly these might supply a needed essential constituent and thus enable the poorer and exhausted seeds to germinate by converting certain seed products into a form available for germination. The seeds used were Medicago sativa, Brassica napus, Vicia sativa, Fagopyrum esculentum, Ornithopus sativus and Canadian Field Pea. Asparagin and leucin increased the percentage of germination and in some cases gave an accelerated germination. However, a persin solution gave fair results with some seeds and negative results with others. Diastase, one of the most widely distributed enzymes, gave beneficial results with some seeds but with others results of no consequence were secured. Thus it seems that the enzyme

\footnotetext{
16 Experiment Station Record Vol. 27 p. 132

17 Experiment Station Record Vol. 25 p. 222

18Stone \& Smith, Hass. Hatch Exp. Sta. Report 1901 pp. 74-79
} 

must be fitted to the particular seed.

Waugh found, thus confirming the earlier work of Thomsen, that the percentage of germination of some seeds may be greatly increased by soaking for several hours in a solution containing some active enzyme. Tomato seeds seemed to respond exceptionally well to the action of diastase. The action of the various solutions apparently is to convert a large amount of the starch content and it can hardly be questioned but that this is to the advantage of the germinating seed. Pickering reports that heating a soil seems to have the effect of retarding the germination of seeds planted in it. This was supposed to be due to an inhibitory substance formed by the alteration of the bacterial content of the soil. The fact that heating a soil increases the soluble organic and nitrogenous matter present and also that these materials form a large proportion of the inhibitory substance, lends support to such a view. Fletcher (1910) also reported that a heated soil seemed to retard germination.

Electric Stimulation---Many investigators have been interested. In the effect of an electric current on plant life in general, but Nollet was the first to apply it as a stimulus

19waugh, Vermont Station Report 1898 pp. 290-295 20 Pickering, 9th Report Woburn Experiment Fruit Farm 21 Experiment Station Record V01. 23 p. 722 22 Except where otherwise noted, this account is taken from Mass. Hatch Experiment Station. Bulletin 43 . 

to seeds. Iater specnew subjected different seeds to electric treatment and found that germination was very greatly hastened. Paulin found that electricity would awaken life in seeds which had apparently lost all vitality. He used soaked seeds and declared that the seeds must be planted while still moist or the electrical effect would all be lost.

Tschinkel showed that certain seeds germinated quicker in a soil through which an electric current had been passed, but Woolny secured only negative results from the use of this treatment on seeds of summer rye, radish and rape.

After considerable work along various lines with the effect of electricity on the seeds of Trifolium pratenso, Brassica napus and Brassica alba, Kinney comes to the following conclusions: "Electricity exerts an appreciable influence upon the germination of seeds and the application of certain strengths of current to seeds for short periods accelerates the process of germination." Treated seeds gave a higher germination earlier and a greater total germination than the untreated lot. The experiments showed that there is an optimum as well as a maximum and minimum current and also that the range of current stimulating rapid germination is exceedingly limited. The effect of a single application of the current lasted only a short time but hourly applications acted as a constant stimulus.

It has also been reported that a galvanic current of high frequency would give beneficial results but a continued

23Kinney, Mass. Hatch Experiment Station Bulletin 43. 

current proved to be detrimental to seed germination.

Contact Stimulation---Heinricher 25 (1909) made a

study of the seed germination of parasites. He found that the seeds of Lathraea would not germinate unless they were in contact with the host. Bartschia seeds germinated without the stimulus of the host plant but rozzia, a related gencios, failed to germinate unless in close proximity to the host.

Iight and Heat Stimulation---It is quite generally known that light and heat have great influence on germination and much literature is avaliable.

Promsy and Drevon ${ }^{26}$ found that the $\mathrm{X}$-ray had a variable effect on the seeds of lentils, wheat, beans, and lupines at ordinary temperatures, but with moderately high temperatures the phenomena became regular. With the exposure adapted, however, the irradiation always favored gerinination and accelerated the development of the plants.

Immaturity as a Cause of Early Germination---Although green or immature seeds do not germinate usually as large a percentage as more mature ones ${ }^{27}$ yet they are sometimes used in order to secure earlier developing plants. This is especially true of tomatoes. Maze 28 induced early maturity in the seeds by arying corn kernels containing 50-60\% moisture for five or

\footnotetext{
24Experiment Station Record Vol. 25 p. 26

25Experiment Station Record Vol. 23 p. 628

26Experiment Station Record Vol. 28 p. 128

27 Read, Thesis 1908, Univerrity of Missouri 28Experiment Station Record Vol. 24 p. 720
} 

six days. The dried seed would then yield normal plants. He advances three theories to explain the results but he seems to favor the following as the most probable: Evaporation of the volatile matter tends to retard the growth of the embryo and hence aids in the normal developient.

Stimulation from Anesthetics 29 -The whole question of how vapors and gases cause growth to begin in dormant plants is little understood. According to Hempel, Clemens and larcet (1848) were the first to study the effects of anesthetics or plants. They used chloroform to suspend the irritability of IIimosa. Leclerc (1853) investigated the effects of ether on plants. His work was followed by that of Blondeau (1867) and Bert (1867). Heckel (1873-4) noted the behavior of Berberis stamens under the influence of chloroform. Later he studied the sensitiveness and movements of other plants as affected by various anesthetics and narcotics. About the same date Pfeffer decided that the sleen movements of rimosa were eliminated in an atmosphere of ether but he was of the opinion that such treatment would injure the plant.

The first record of a study of the effect of ether on seeds appears in the work of Giglioli (1868) who studied extensively the effect of gases and liquids on the vitality of seads. 30 Ether was used in both the gaseous and liquid forms on both wet and dry seeds. The conclusion reached was that wet seeds were

\footnotetext{
29Unless otherwise noted, this account is taken from Henpel's work - "Researches into the Liffect of Etherization on Plant Metabolism."
}

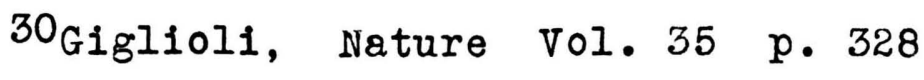



more easily killed than the dry ones but he does not state whether germination was hastened or not. Bernard, sirgusa (1879), Detmer (1882), and Dubols (1891) agreed that ether retarded the growth of seodlings and prevented the germination of seeds but that when the etherizing influence was withdrawn, growth and germination went forward. Dubois also reports a strong dehydrating effect of ether, thus suggesting the possibility that it is very similar in its action to drying and freezing.

Townsend ${ }^{31}$ (1897) tested the effects of ether on seeds of Zea liais, Avena sativa, Phaseolus vulgaris and Cucurbita Pepo. The seeds were placed in an ether atmosphere and allowed to remain there continuously. He found that while a strong atmosphere tends to retard or prevent germination, a weak one has the effect of hastening this process. Different seeds seemed to be affected differently by the same treatment. Seeds which had been kopt from germinating several days by a strong ether atmosphere, germinated quite readily when removed to an etherfreo atmosphere. Although the treated seeds germinated more readily yet it was noticed that the untreated seeds later overtook them in point of growth.

Johannsen (1893) diminished the rest period of seeds by etherization but he states that the rest period could be broken only at its beginning or toward its close. After the rest period had passed no stimulation of germination was noticed. He supposed that anesthetics acted in either one or both of two

31 Townsend, Botanical Gazette $27: 458-66$ 

ways, on the "power of growth" (Wachstumstatigkeit) or on the "growth suspending power" (Hemmung).

Although the results usually secured from freezing and desiccation are the same as those from the use of anesthetics, yet Johannsen states that these results do not come from the same cause. In support of this theory, he cites the case of Hordeum zeocrithon which has a pronounced rest period. While slight ether fumes stimulated immediate germination, drying had no apparent effect. He differs with Dubois on the question of etherization increasing the transpiration but it has since been demonstrated - at least in the case of twigs - that such treatment does tend to increase transpiration.

Coupin (1899) experimented with both air dry and soaked seeds and he concluded that anesthetics could affect only active protoplasm since they did not influence the active seeds and retarded the soaked ones. Schmid (1901) gave as his opinion that anesthetics acted as a poison to active protoplasm.

Behrens (1908) shortened the resting phase of seeds by exposure to ether thus causing them to germinate almost immediately. He supposed this acceleration was due to a direct stimulation rather than to an indirect effect on the seed coat enabling it in some way to absorb moisture more readily. Eberhard (1906) had held the same views.

While all vital processes are retarded or quickly arrested by the influence of anesthetics or narcotics, the cherical processes are never retarded, and in some cases are accelerated,

32 Howard, Missouri Exp. Station Research Bul. I. 

by such an influence. Such was the opinion of Bernard and for this reason he held that respiration, a chemical process as he thought, would be unaffected by etherization. It has been proven that anesthetics do affect ferments but the opinions as to their action on enzymes are somewhat divided.

In regard to the relation of etherization and transpiration, Jumelle (1890) and Lommen believed that transpiration was accelerated and assimilation suspended by anesthetics but Schneider (1893) thought that an ether atmosphere always reduced transpiration. Woods and Dixon (1896) also held the same opinion as Schneider but they concluded that it was from a physical cause and that transpiration and evaporation were identical. Gayon (1877) had found that an ether atmosphere suspended the evolution of $\mathrm{CO}_{2}$ but Elfving reported an acceleration of respiration in Pisum seedlings when exposed to the influence of ether. Lauren states that seeds rich in carbohydrates could not have their respiration increased since respiration could be accelerated only in proportion to the amount of nitrogenous matter contained in the seed and Abrahamson's ${ }^{33}$ (1910) work showeded that a high protein content in barley was correlated with a high respiration. Johannsen proved that in ripening lupines and sweet peas respiration was slightly retarded by etherization but in young ripening barley seeds it was increased. Thus it seems that the specific effect of ether on respiration depends quite largely on the kind of seed being tested.

Hempel experimented extensively concerning the effect

33 Experiment Station Record Vol. 24 p. 629 

of etherization on plant metabolism but the only part of that work of interest here deals with the effect of ether on ripening seeds of Pisum and Iupinus. It was found that etherizing germinating seeds retarded both the germination and also the subsequent growth. The effect of small doses for short periods was to accelerate the production of $\mathrm{CO}_{2}$ but large doses retarded 1t. Respiration was never increased as an "after effect." The sugar forming process was not so vitally affected as the respiratory process and, because of the relation of the inversion of sugar to the other processes, it was thought that the retardation of the $\mathrm{CO}_{2}$ production might be due to a lack of hexoses. Young Pisum seeds showed a hastening of the condensation of protelds normally taking place at maturity, when small doses of ether were used. Iarge doses retarded the synthesis of proteids or destroyed those already formed. Ether retarded the decrease of amides at ripening time in mono-amino seeds but small doses seemed to slightly increase it in di-amino seeds. Wounded seeds were not affected by small doses of ether but large doses tended to produce an increase in the amides during the two days' exposure.

As a summary of the work, Hempel recognizes three phases of narcotization: IExciting (small doses for short periods) during which time the normal plant activities are accelerated; 2 Narcosis proper (small doses for long periods or large doses for short periods) characterized by a retardation of the normal processes; and 3 Toxic (large doses for long periods) causing all the phenomena characteristic of the death of the plant. 

Lewis ${ }^{34}$ (1906) reported quicker germination and more uniform growth from seeds which have been etherized than from untreated seeds. Taubenhaus ${ }^{35}$ (1908) reported very similar results and he also stated that ether seemingly put new life into old seeds thereby causing a higher germination. In both of these tests the seeds used were those of common vegetables and grains.

Kiessling ${ }^{36}$ (1911) found that an 80 minute exposure to ether would hasten the germination of seods but longer doses reduced both the rapidity and total per cent of germination. Alcohol, chloroform, etc., acted as stimulants to barley, wheat and oats. Injury to the seed, especially to the hulls tended to promote increased and hastened germination.

Aspit and $\mathrm{Gain}^{37}$ (1911) showed that the effect of ether was considerably increased at high temperatures.

Miscellaneous Work---Waldron ${ }^{38}$ (1904) in making a study of the vitality of buried seed found that green and yellow foxtall would not germinate before about Nay 1 of the year following the production of the seed. Kinghead grew more abundantly the second season following planting than the one immediately following planting. The ability of some seeds to germinate seemed to depend quite largely upon the depth to which thoy were planted,

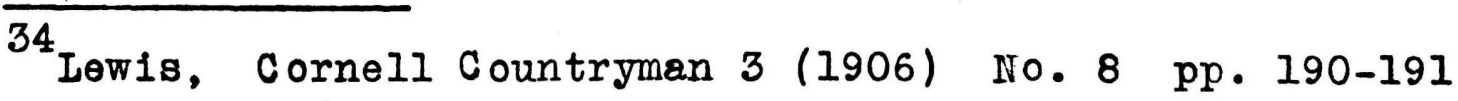
35 Taubenhaus, Cornell bountryman 5 (1908) No. 6 p. 201 36 Experiment Station Record V01. 26 pp. 130-131 37

Experiment Station Record Vol. 27 p. 220 $38_{\text {Waldron, N. D. Experiment Station Bulletin } 62}$
} 

the deeper burled ones (up to ten inches) being the better preserved ones. It was also shown that some seed maintained their vitality much longer than others kept under the same conditions. Fawcett ${ }^{39}$ (1904) made a study of the viability of seeds under different conditions of treatment and also of their dormant periods. Seeds stored indoors showed almost uniformly a longer dormant period than those stored outside, and the longest dormant periods occurred in those seed with the hardest and thickest seed coat. Some seeds showed a gradual decrease in the percentage of germination from month to month but others showed an increase. There seemed to be two natural periods for seed germination, one in the fall and the other in the spring. Exposing seed to the action of the weather tended to increase the percentage of germination and also shorten the dormant period.

Pammel and King ${ }^{40}$ (1906) in a study of delayed germination confirmed some of the earlier work of Fawcett. It was reported that the seeds of many plants such as the willows, soft maple, etc., germinated immediately but others such as the ash and hornbeam did not germinate until the following year. In the case of many trees and shrubs maturing their seed early in the season, it was thought that germination must proceed immediately or the seods would be destroyed.

It has long been known that in the case of some paired seeds such as the cocklebur, both seeds do not usually germinate

\footnotetext{
39 Fawcett, Proc. Iowa Acad. of Science Vol. 15, No. 38. 40 Pammel \& King, Proc. Iowa Acad. Science Vol. 15, No. 45.
} 

the same season. Arthur, ${ }^{41}$ who made the first careful study of Xanthium, reported that generally the germination of one kernel in the bur was delayed but that in some cases both may germinate the same season. Shull 42 (1911) in further investigations with Xanthium found that the minimum oxygen requirement for the germination of the seed from this plant was abnormally high and also that the minimum for the two seeds differed. Thus the delay in germination and also the difference in the delay is secured. Beal $^{43}$ (1910) gives some interesting data concerning the vitality of buried seeds and incidentally raises some questions concerning their germinating capacities. Eight or nine species out of twenty-two germinated even after they had been buried thirty years. In speaking of his results Beal says: "I have never felt certain that I had induced all the sound seed. to germinate. I moisten the sand containing the seeds and . forthwith a goodly number germinate, and then they come straggling along. I dry the soil and wait a few weeks, and after moistening in a few days, or few months, more seed germinate. Why was I unable to induce them to start, when treated to various degrees of temperature and moisture, for several months?"

\section{EXPER INEENT AL DATA.}

Work on this investigation was begun early in the summer of 1911 and continued until october 1 of that year. As soon

\footnotetext{
4larthur, Proc. Soc. Prom. Agrl. Sc. 16, p. 70. 42shull, Bot. Gazette 52, pp. 453-477 43Beal, Proc. Soc. Prom. Agrl. Sc. 31, pp. 21-23
} 

as seed began to ripen in 1912, it was again taken up and continued until the latter part of July when, on account of serious 1llness, it was interrupted and had to be dropped until october. At that time it was further extended and considerable work was carried on throughout the 1912-13 school year. Some of the later plantings were still under observation on May 1, 1913. In the course of this study, seed from almost two hundred species representing fifty-one orders were collected and over nine hundred samples of seed were planted. The usual number of seed in each sample was one-hundred and hence this investigation represents a planting of nearly one hundred thousand seed.

The most extensive previous work of which any record was found is that of Fawcett ${ }^{44}$ who collected and planted nintytwo samples of seeds representing fifty-two different species. This collection extended over a period of only three months.

The seeds collected, in practically all cases, were from species native to Columbia and vicinity, or from those growing on the University grounds. The system of nomenclature used follows quite largely that used in Gray's nNew lianual of Botany" but a few species were classified from Bailey's"Cyclopedia of American Horticulture."

First Season's Work---During the first summer an attempt was made to secure seed from as large a number of species as possible. The seed were taken just as they were considered fully matured. In some cases it was difficult to decide just when this

44 Fawcett, Proc. Iowa Acad. of Science No. 38, Vol. 15. 

stage was reached but it was assumed that they were mature when they had begun to fall naturaliy or when the fruit had ripened.

A sample of each species was planted immediately after it was collected while another sample was placed in the laboratory and allowed to become thoroughly air ary, when it was planted also. The second planting followed the first one at any interval of approximately one month.

The object of these plantings was to determine which species were capable of germinating immediately upon ripening and to discover those which require further development before germination will take place. At maturity seeds usually contain a much higher percentage of moisture than later, and the seed coats are not nearly so hard as they are when the seeds become air dry. A plentiful supply of moisture and a softened seed coat are conditions conducive to rapid germination and it might naturally be supposed that mature seeds possessing these requirements would germinate more readily than seeds which have become air dry. The fact that the germination of many seeds is apparently dependent upon the moisture supply would seem to bear out this assumption. However, the statement has often been made and, in some instances experimental evidence produced to prove it, that at least some seeds will not germinate as soon as they ripen. All plantings, both of the mature and air dry seeds, were made in sand, in the greenhouse bench. The sand bed was four or five inches deep and was kept molst by froquent sprinkling. All outside conditions such as light, heat, moisture, etc., were made as uniform as possible. 

The data taken covered the number of days the seed remained dormant, that is, the time elapsing between planting and the first germination, and the total percentage of germination.

It was found that over one-half of the one hundred and twenty-five species planted refused to germinate before october 15 when the greenhouse space was required for other purposes. The results secured from the first summer's plantings are given in Table No. I. 

Table No. I

Seeds Planted Both as Soon as Ripe and After Being Air Dried. *ro Germination Before October 15, 1911.

\begin{tabular}{|c|c|c|c|c|c|}
\hline \multirow[b]{2}{*}{ Name of Species } & \multirow[b]{2}{*}{$\begin{array}{c}\text { Date } \\
\text { Collected } \\
\end{array}$} & \multicolumn{2}{|c|}{$\begin{array}{c}\text { Days } \\
\text { Dormant }\end{array}$} & \multicolumn{2}{|c|}{$\begin{array}{c}\text { Total } \% \\
\text { Germination }\end{array}$} \\
\hline & & Mature & Dry & Mature & Dry \\
\hline Gramineae & & & & & \\
\hline $\begin{array}{l}\text { Alopecurus pratensis I. } \\
\text { Hordeum nodosum I. } \\
\text { Bromus mollus I. } \\
\text { Lolium perenne I. } \\
\text { Panicum crus-galli I. } \\
\text { Setaria glauca (I.) Beauv. } \\
\text { Triticum vulgare Vili. } \\
\text { Dactylis glomerata I. } \\
\text { Avena sativa I. } \\
\text { Phleum pratense I. }\end{array}$ & $\begin{array}{l}5 / 20 \\
6 / 9 \\
6 / 15 \\
6 / 21 \\
6 / 24 \\
6 / 30 \\
6 / 13 \\
6 / 15 \\
7 / 3 \\
7 / 22\end{array}$ & $\begin{array}{r}* \\
61 \\
22 \\
14 \\
* \\
48 \\
7 \\
22 \\
16 \\
7\end{array}$ & $\begin{array}{r}50 \\
38 \\
7 \\
6 \\
44 \\
* \\
4 \\
8 \\
4 \\
8\end{array}$ & $\begin{array}{r}0 \\
90 \\
57 \\
52 \\
0 \\
14 \\
66 \\
32 \\
23 \\
71\end{array}$ & $\begin{array}{r}5 \\
96 \\
84 \\
53 \\
2 \\
0 \\
96 \\
59 \\
71 \\
90\end{array}$ \\
\hline Cjperaceae & & & & & \\
\hline $\begin{aligned} \text { Cyperus } & \text { sp. } \\
& \text { Liliaceae }\end{aligned}$ & $6 / 24$ & * & 11 & 0 & 48 \\
\hline $\begin{array}{l}\text { Asparagus officinalis } \mathrm{I} \text {. } \\
\text { Yucca filamentosa I. } \\
\text { Canna sp. }\end{array}$ & $\begin{array}{l}8 / 3 \\
8 / 8 \\
8 / 26\end{array}$ & $\begin{array}{r}8 \\
19 \\
16\end{array}$ & $\begin{array}{l}11 \\
28 \\
35\end{array}$ & $\begin{array}{l}93 \\
61 \\
22\end{array}$ & $\begin{array}{r}57 \\
27 \\
7\end{array}$ \\
\hline Urticaceae & & & & & \\
\hline $\begin{aligned} \text { Morus alba } & \text { I. } \\
& \text { Polygonaceae }\end{aligned}$ & $6 / 5$ & 13 & 8 & 42 & 57 \\
\hline $\begin{array}{r}\text { Rumex crispus } \mathrm{L} . \\
\text { Phytoleccaceae }\end{array}$ & $6 / 5$ & 18 & 22 & 73 & 71 \\
\hline $\begin{array}{r}\text { Phytolacca decandra I. } \\
\text { Caryophyllaceae }\end{array}$ & $8 / 25$ & 26 & * & 42 & 0 \\
\hline $\begin{array}{l}\text { Lychnis calcedonica I. } \\
\text { Saponaria officinalis } \mathrm{I} \text {. } \\
\text { Iychnis alba Mill. }\end{array}$ & $\begin{array}{l}6 / 22 \\
7 / 13 \\
8 / 26\end{array}$ & $\begin{array}{r}45 \\
16 \\
7\end{array}$ & $\begin{array}{r}10 \\
40 \\
6\end{array}$ & $\begin{array}{r}1 \\
3 \\
34\end{array}$ & $\begin{array}{r}20 \\
5 \\
35\end{array}$ \\
\hline
\end{tabular}





\begin{tabular}{|c|c|c|c|c|c|}
\hline Ranunculaceae & & & & & \\
\hline $\begin{aligned} \text { Aquilegia } & \text { sp. } \\
& \underline{\text { Berberidaceae }}\end{aligned}$ & $6 / 12$ & 21 & 20 & 40 & 48 \\
\hline $\begin{array}{r}\text { Berberis vulgaris } I . \\
\text { Cruciferae }\end{array}$ & $9 / 8$ & 56 & 38 & 2 & 19 \\
\hline $\begin{array}{c}\text { Sisymbrium officinale (I.) Scop. } \\
\text { Leguminosae }\end{array}$ & $6 / 23$ & $*$ & 21 & 0 & 40 \\
\hline $\begin{array}{l}\text { Baptisia australis (I.) R. Br. } \\
\text { Trifolium pratense I. } \\
\text { Caragana aborescens Lam. } \\
\text { Pisum sativum I. } \\
\text { Medicago sativa I. } \\
\text { Lathyrus latifolius I. } \\
\text { Melilotus alba Desr. } \\
\text { Gymocladus dioica (..) Koch } \\
\text { Robinia Pseudo-Acacia I. } \\
\text { Gleditsia triaeanthos I. }\end{array}$ & $\begin{array}{l}6 / 26 \\
6 / 12 \\
6 / 12 \\
6 / 22 \\
7 / 13 \\
7 / 14 \\
7 / 19 \\
8 / 3 \\
8 / 25 \\
8 / 3\end{array}$ & $\begin{array}{r}14 \\
33 \\
10 \\
3 \\
8 \\
6 \\
8 \\
10 \\
9 \\
6\end{array}$ & $\begin{array}{r}2 \eta \\
* \\
\eta \\
2 \\
8 \\
14 \\
* \\
20 \\
* \\
11\end{array}$ & $\begin{array}{r}34 \\
2 \\
96 \\
61 \\
69 \\
60 \\
4 \\
85 \\
1 \\
25\end{array}$ & $\begin{array}{r}28 \\
0 \\
78 \\
52 \\
71 \\
79 \\
0 \\
85 \\
0 \\
22\end{array}$ \\
\hline Oxalidaceae & & & & & \\
\hline $\begin{array}{r}\text { Oxalis Acetosella I. } \\
\text { Geraniaceae }\end{array}$ & $6 / 22$ & * & 47 & 0 & 4 \\
\hline $\begin{array}{r}\text { Geranium carolinianum I. } \\
\text { Celastraceae }\end{array}$ & $6 / 9$ & 88 & 37 & 13 & 35 \\
\hline $\begin{array}{r}\text { Celastrus scandens } \mathrm{I} . \\
\underline{\text { Malvaceae }}\end{array}$ & $8 / 30$ & 6 & * & 3 & 0 \\
\hline $\begin{array}{l}\text { Walva rotundifolia I. } \\
\text { Althaea rosea Cav. } \\
\text { Abutilon Theophrasti wedic } \\
\text { Hibiscus Moschentos L. }\end{array}$ & $\begin{array}{l}6 / 22 \\
6 / 29 \\
8 / 3 \\
8 / 3\end{array}$ & $\begin{array}{r}* \\
6 \\
16 \\
6\end{array}$ & $\begin{array}{r}45 \\
6 \\
24 \\
*\end{array}$ & $\begin{array}{r}0 \\
73 \\
7 \\
69\end{array}$ & $\begin{array}{r}1 \\
72 \\
15 \\
0\end{array}$ \\
\hline Umbelliferae & & & & & \\
\hline $\begin{array}{r}\text { Pastinaca sativa } \mathrm{I} . \\
\text { Solanaceae }\end{array}$ & $6 / 30$ & 66 & 18 & 3 & 4 \\
\hline 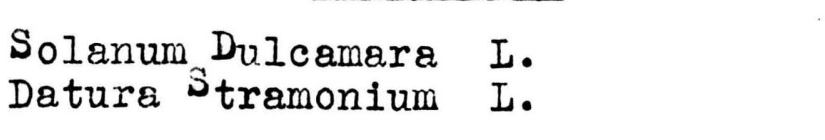 & $\begin{array}{l}9 / 14 \\
9 / 14\end{array}$ & $\begin{array}{r}9 \\
30\end{array}$ & $\begin{array}{l}19 \\
17\end{array}$ & $\begin{array}{l}70 \\
22\end{array}$ & $\begin{array}{l}46 \\
90\end{array}$ \\
\hline
\end{tabular}





\begin{tabular}{|c|c|c|c|c|c|}
\hline Bignoniaceae & & & & & \\
\hline $\begin{array}{r}\left.\text { Tecoma radicans ( } \mathrm{I}_{\bullet}\right) \text { Juss. } \\
\text { Plantaginaceae }\end{array}$ & $9 / 12$ & 20 & 4 & 33 & 8 \\
\hline $\begin{array}{r}\text { Plantago virginica } I_{.} \\
\text {Plantago lanceolata } I_{.} \\
\text {Caprifoliaceae }\end{array}$ & $\begin{array}{l}6 / 19 \\
6 / 30\end{array}$ & $\begin{array}{r}30 \\
8\end{array}$ & $\begin{array}{l}* \\
6\end{array}$ & $\begin{array}{r}3 \\
20\end{array}$ & $\begin{array}{r}0 \\
33\end{array}$ \\
\hline $\begin{array}{l}\text { Lonicera taftarica } I . \\
\text { Cucurbitaceae }\end{array}$ & $6 / 20$ & 66 & 18 & 2 & 30 \\
\hline $\begin{array}{c}\text { Citrullus vulgaris Schrad. } \\
\text { Compositae } \\
\end{array}$ & $8 / 26$ & 7 & 6 & 18 & 35 \\
\hline $\begin{array}{l}\text { Taraxacum officinale Weber. } \\
\text { lactuca Scariola I. } \\
\text { Chrysanthemum leucanthemum I. } \\
\text { Gailardia sp. } \\
\text { Centhrea grandiflora Hort. } \\
\text { Rudbeckia hirta I. } \\
\text { Zinnia elegans Jacq. } \\
\text { Echinops sphaerocephalus I. } \\
\text { Arti mum minus Bernh. } \\
\text { Helianthus annus I. }\end{array}$ & $\begin{array}{l}5 / 20 \\
6 / 8 \\
6 / 21 \\
6 / 22 \\
6 / 28 \\
7 / 20 \\
7 / 24 \\
8 / 8 \\
8 / 29 \\
9 / 6\end{array}$ & $\begin{array}{r}70 \\
21 \\
* \\
75 \\
17 \\
* \\
8 \\
17 \\
14 \\
*\end{array}$ & $\begin{array}{r}* \\
9 \\
42 \\
27 \\
10 \\
10 \\
4 \\
10 \\
9 \\
9\end{array}$ & $\begin{array}{r}7 \\
14 \\
0 \\
2 \\
28 \\
0 \\
23 \\
8 \\
4 \\
0\end{array}$ & $\begin{array}{r}0 \\
21 \\
1 \\
5 \\
27 \\
22 \\
52 \\
2 \\
68 \\
40\end{array}$ \\
\hline Average for all species in Table & & $22 \cdot 2$ & 17.8 & 33.3 & 40.9 \\
\hline
\end{tabular}



The following list includes those species from which no germination was secured:

\section{Gramineae}

Poa pratensis I. Eragrostis rajor I.

Cyperaceae

Carex sp.

Carex Frankii Kunth.

Carex sp. Cyperus strigosus I.

Betulaceae

Ostrya virginiana (nill.) K.Koch

Polygonacere

Rumex Acetosella I.

Amaranthaceae

Amaranthus spinosus I. Amaranthus sp.

Caryophyllaceae

Silene antirrhina $I$.

Portulaceae

Portulaca oleracea I.

Cruciferae

Capsella bursa-pastoris (I.) Wedic. Lepidium virginicum I.

Saxifragaceae

Ribes nigrum I. Ribes gracile lichx.

Rosaceae

Agrimonia microcarpa Vallr.

Prunus verasus I.

Fragaria virginiana Duchesne.

Prunus hortulana Bailey

Rubus occidentalis I.

Rubus villosus Ait.

Prunus Persica (I.) Stokes

Amelanchier candensis (I.)

Pyrus Malus I.

Rosa rugosa I.

Physocarpus opulifolius (I)

Crataegus sp.

(Waxim.

Ieguminosae

Trifolium repens I. Cercis canadensis I. 



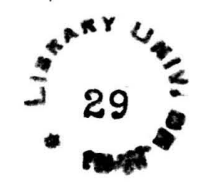

$\underline{\text { Rutaceae }}$

Ptelea trifoliata I.

Zanthoxylum anericanum bill.

Anacardaceae

Rhus canadenis Marsh Rhus moxicodendron I.

Rhus glabra I.

Staphy̆leaceae

Staphylea trifolia I.

Sapindaceae

Koelreuteria paniculata Laxm.

Rhamflnaceae

Rhamnus cathartica I.

\section{Vitacere}

Vitis labrusca I.

Vitis riparia Michx.

Ampelopsis quinquefolia Michx.

Tiliaceae

Tilia americana $I$.

Elaeagnaceae

Elaeagnus argentia Pursh. Elaeagnus multiflora Thunb.

Umbelliferae

Chaerophyllum procumbens (I.) Crantz.

Osmorhiza longistylis (Torr) DC.

Cornaceae

Cornus stolonifera Michx. Cornus Baileyii Coult.\& Evans.

Ebenaceae

Diospyros virginiana I.

Oleaceae

Chionanthus virginica I. Fraxiaus americana I. Asclepiadaceae

Asclepias sp. 

Iabiatae

Blephiflia ciliata (L.) Raf.

Solanaceae

Solanum carolinense L. Solanum Helongena I.

Scrophulariaceae

Verbascum Blattaria I.

Plantaginaceae

Plantago major I. Plantago aristata Michx.

Rubiaceae

Galium Aparine I.

Caprifoliaceae

Sambucus canadensis I.

Compositae

Cirsium pumilum (Nutt) Spreng. Helifanthus laevigatus T \& G.

Coreopsis sp. Bidens bipinnata I. 

A review of the foregoing table and list brings out some interesting facts. Probably the most prominent one presented is that some species seem to possess the capacity for prompt germimation immediately after ripening while others apparently must have a period of rest before growth will begin. the species of

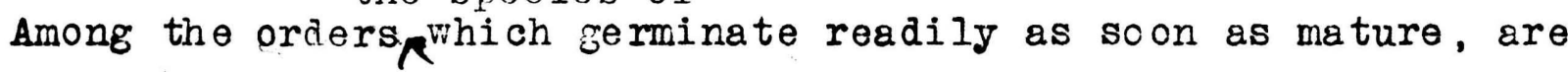
found Gramineae, Liliaceae, Caryophyllaceae, Malvaceae and Compositae, while those which tend to have delayed germination include Cyperaceae, Rosaceae, Anacardaceae and Vitaceae. The first plantings (In this discussion, "first planting" always has reference to seeds which were planted immediately after ripening, and "second planting" to seeds which had been air dried for one month before being placed under growing conditions, of Liliaceae and Leguminosae, as a general rule, gerininated quicker and gave a higher percentage of germination than the second plantings, but the results from plantings of compositae and Gramineae were exactly the reverse. These two observations would seem to indicate that the seeds of the various species in an order are similar in some respects.

$$
\text { of the fifty-eight species which showed ability to }
$$
germinate, nine gave no results from the planting of mature seeds and nine others none from the planting of the air dry seeds. lwenty-six of the remaining species, however, gave a quicker germination from the second planting than from the first, thus indicating the presence of a rest period. This brings out the fact that the seeds from a majority of the species studied re- 

quire an interval of rest after্ maturity before the $\mathrm{W}$ wil ger minate, and also indicates that this interval is shorter one month after maturity than it is at maturity.

The average length of the dormant period following the first planting was 22.2 days while after the second planting it was 17.8 days, thus showing a decrease of 4.4 days.

The fact that seeds germinate more readily after becoming air dry is also brought out by the percentage of germination obtained. Twenty-six species gave a higher total germination from the second planting than from the first, while the reverse was true in only thirteen cases. The average increase in germination due to the later planting was $6.6 \%$.

In nearly every case the higher percentage of germination was correlated with the shorter dormant period. This might indicate that there is some relationship between the length of the dormant period and the percentage of germination. Second Season's Work. Although the tirst summer's work had brought out some interesting points, it was desirea to turther corroborate them by more extended study and with this idea in view the work of the second season was planned. As in the previous work, as large a collection as possible was made of seeds from species in and about columbia, but the collecting began earlier and was much more extensive:

The seeds were collected as before just as they were mature but all plantings were made in an out-door bed of well drained soil instead of in sand in a greenhouse bench. It had 

been impossible to allow the seed of the previous planting to remain undisturbed until the following spring or until all hopes of further germination were gone and hence it was felt that this test had been incomplete. It was planned to allow the new test to proceed until the seeds had either all germinated or decayed. Then, too, it was thought that more natural conditions would be secured and all artificial stimulation avoided by the out-door plantings. The soil used was a mixture of loam and sand and was kept moist by sprinkling when necessary. During the suinmer months a partial shade was provided by using muslin covers. At the approach of winter a thick mulch was spread over the bed. This mulch was removed before the growing season began in the spring.

The work was also somewhat broadened by the collection and planting of immature seeds. These seeds were taken when they were in the condition spoken of as the"dough stage." For the most part all species used in this way were woody plants and two plantings were usually made, one immediately after collecting and the second one after some of these immature seeds had become air ary.

The work of this season was necessarily abruptly dropped in the latter part of July, on account of illness, and hence the data are not as complete as were hoped for. However, in spite of this, some rather striking points were brought out by the data secured.

Although a planting of the air-dry mature seeds of soveral species was made, yet the results from these plantings 

are not given because they are so few in number and also because, in the main, they bring out the same points as Table No. I.

The germination of the seeds planted when mature naturalIf classifies them into three groups and for this. reason the results of this work are given in three tables. A fourth is used for the seeds planted while still immature. These four tables follow. 

Table No. II

Seeds Planted at Naturity, Showing Immediate Germination.

\begin{tabular}{|c|c|c|c|}
\hline Name of Species & $\begin{array}{l}\text { Date } \\
\text { Collected } \\
\end{array}$ & $\begin{array}{c}\text { Days } \\
\text { Dormant }\end{array}$ & $\begin{array}{c}\text { Total } \\
\text { Germination }\end{array}$ \\
\hline \multicolumn{4}{|l|}{ Gramineae } \\
\hline $\begin{array}{l}\text { Secale cereale I. } \\
\text { Triticum vulgare Vill. } \\
\text { Avena sativa I. } \\
\text { Bromus ciliatus L. } \\
\text { Hordeum sativum Jess } \\
\text { Lolium perenne I. }\end{array}$ & $\begin{array}{l}7 / 1 \\
7 / 2 \\
7 / 12 \\
7 / 13 \\
7 / 13 \\
7 / 13\end{array}$ & $\begin{array}{r}7 \\
7 \\
24 \\
11 \\
6 \\
11\end{array}$ & $\begin{array}{l}29 \\
30 \\
34 \\
24 \\
36 \\
37\end{array}$ \\
\hline Liliacere & & & \\
\hline $\begin{array}{c}\text { Asparagus officinale } \mathrm{L} \text {. } \\
\text { Urticaceae }\end{array}$ & $7 / 3$ & 26 & 46 \\
\hline $\begin{array}{l}\text { Ulmus scabra Mill } \\
" \text { fulva Michx } \\
\text { " americana I. } \\
\text { Morus alba L. }\end{array}$ & $\begin{array}{l}5 / 9 \\
5 / 15 \\
5 / 9 \\
6 / 15\end{array}$ & $\begin{array}{l}14 \\
17 \\
13 \\
17\end{array}$ & $\begin{array}{r}18 \\
2 \\
15 \\
2\end{array}$ \\
\hline Ieguminosae & & & \\
\hline $\begin{array}{c}\text { Caragana aborescens Lam. } \\
\text { Aceraceae }\end{array}$ & $7 / 2$ & 8 & 81 \\
\hline $\begin{array}{c}\text { Acer saccharinum } I . \\
\underline{\text { Malvaceae }}\end{array}$ & $5 / 15$ & 9 & 55 \\
\hline $\begin{array}{r}\text { Althaea rosea Cav. } \\
\text { Umbelliferae }\end{array}$ & $7 / 20$ & 4 & 53 \\
\hline $\begin{array}{c}\text { Pastinaca sativa } \mathrm{I} . \\
\text { Solanaceae }\end{array}$ & $7 / 6$ & 18 & 3 \\
\hline $\begin{array}{r}\text { Solanum Dulcamara I. } \\
\text { Cucurbitaceae }\end{array}$ & $7 / 15$ & 9 & 51.5 \\
\hline $\begin{array}{r}\text { Cucumis Melo I. } \\
\text { Compositre }\end{array}$ & $7 / 18$ & 6 & 97 \\
\hline Centurea grandiflora Hort. & $7 / 5-$ & 19 & 5.5 \\
\hline
\end{tabular}



Table No. III

Seeds, Planted Imrediately After liaturity, Showing

Germination in the Fall, oct. 30, 1912 .

\begin{tabular}{c|c|c|}
\hline Name of Species & $\begin{array}{c}\text { Date } \\
\text { Collected }\end{array}$ & $\begin{array}{c}\text { Total } \\
\text { Germination }\end{array}$ \\
\hline $\begin{array}{c}\text { Geraniaceae } \\
\text { Geranium carolinianum L. }\end{array}$ & $6 / 8$ & 22. \\
Gubiaceae & $6 / 20$ & 81. \\
Lactum Aparine L. & $6 / 21$ & 5. \\
\hline
\end{tabular}

Table iro. IV

Seeds, Planted at laturity, Showing Germination

in the Following Spring, April 16, 1913.

\begin{tabular}{c|c|c|}
\hline Name of Species & $\begin{array}{c}\text { Date } \\
\text { Collected }\end{array}$ & $\begin{array}{c}\text { Total } \\
\text { Germination }\end{array}$ \\
\hline Gramineae & & \\
lielica mutica Walt. & $6 / 25$ & 25.0 \\
Dactylis orlomerata I. & $6 / 27$ & 47.5 \\
Phleum pratense I. & $7 / 13$ & 9.0 \\
Hordeum nodosum I. & $6 / 8$ & 8.5 \\
Commelinaceae & & \\
Tradescantia reflexa Raf. & $6 / 24$ & 7.5 \\
Liliaceae & & \\
Trillium sosile I. & $7 / 1$ & 50.0
\end{tabular}



Polygonaceae

Rumex obtusifolius I. crispus I.

\section{Saxifragaceae}

Ribes gracile lifichx.

$$
\text { Rospacere }
$$

Prunus hortulana Bailey

Leguminosae

Trifolium $\underset{\text { repens }}{\text { pratense }}$ I.

Anacardaceae

Rhus canadensis liarsh

\section{Balsaminaceae}

Impatiens pallida Nutt.

Violacere

Viola pubescens Ait.

" papilionacea Pursh.

Hybanthus concolor (Forster) Spreng

Umbelliferae

Osmorhiza longistylis (Torr) DC

Pimpinella Saxifraga $\mathrm{I}$.

\section{Oleacere}

Fraxinus quadrangulata lifichx.

Hydrophyllaceae

Ellisia Nyctella $\mathrm{I}$.

Boraginaceae

Cynoglossum officinale I.

Plantaginacere

Plantago lanceolata I.

\begin{tabular}{|c|c|}
\hline $\begin{array}{l}7 / 2 \\
6 / 19\end{array}$ & $\begin{array}{l}48.0 \\
12.5\end{array}$ \\
\hline $7 / 5$ & 13.5 \\
\hline $7 / 19$ & 5.0 \\
\hline $\begin{array}{l}6 / 25 \\
7 / 2\end{array}$ & $\begin{array}{l}40.0 \\
57.0\end{array}$ \\
\hline $6 / 20$ & 5.0 \\
\hline $\begin{array}{l}6 / 22 \\
7 / 9\end{array}$ & $\begin{array}{r}78.0 \\
28.0\end{array}$ \\
\hline $\begin{array}{l}6 / 21 \\
6 / 21 \\
6 / 26\end{array}$ & $\begin{array}{l}20.8 \\
65.0 \\
27.0\end{array}$ \\
\hline $\begin{array}{l}7 / 5 \\
7 / 12\end{array}$ & $\begin{array}{l}40.0 \\
11.0\end{array}$ \\
\hline $6 / 25$ & 4.0 \\
\hline $6 / 8$ & 31.5 \\
\hline $6 / 28$ & 36.0 \\
\hline $7 / 14$ & 40.0 \\
\hline
\end{tabular}



Compositae

Centhrea grandiflora Hort.

Coreopsis lanceolata I.

Gaillardia pulchella Fouq.

\begin{tabular}{l|l} 
& \\
$7 / 5$ & \\
$7 / 5$ & 23.5 \\
$7 / 5$ & 10.0 \\
& 17.0
\end{tabular}

Seed from the following species refused to germinate

inside of ten months when planted immediately after maturity:

Gramineae

Bromus hordeacus I.

Cyperaceae

Carex Shortiana Dewey

" gravida Bailey

Carex Muhlenbergii Schkuhr.

\section{Iiliaceae}

Allium canadense I.

Betulaceae

Betula alba I.

Betula nigra $I$.

Nyctaginaceae

Oxybaphys floribundus Chois.

Ranunculaceae

Aquilegia sp.

Aquilegia canadensis I.

Anonaceae

Asimina triloba Dunal.

Berberidaceae

Podophyllum peltatum I.

Cruciferae

Lepidium virginicum I. Arabis canadensis I. 



\section{Rossceae}

Potentilla monspliensis I.

Prunus Cerasus I.

" virginiana $I$.

Ieguminosae

Strophostyles helvola (I.) BSP.

Staphyleaceae

Staphylea trifolia I.

Malvaceae

Abutilon Theophrasti liedic.

Plantaginaceae

Plantago virginica $\mathrm{L}$.

Caprifoliaceae

Ionicera taftarica I.

Compositae

Taraxacum officinale Weber.
Rubus strigosus lichx.

" occidentalis I.

" nigrobaccus Bailey
Plantago aristata Iichx.

Sonchus asper (I.) Hill. 

Table No. V

Seeds Planted While Immature

*No Germination

\begin{tabular}{|c|c|c|c|c|}
\hline \multirow{2}{*}{ Name of Species } & \multicolumn{2}{|c|}{ Days Domant } & \multicolumn{2}{|c|}{$\begin{array}{l}\text { Total } \\
\text { Germination }\end{array}$} \\
\hline & Green & Nature & Green & Wature \\
\hline Rosacere & & & & \\
\hline $\begin{array}{r}\text { Pyrus malus } I . \\
\text { Saxifragaceae }\end{array}$ & * & 57 & 0 & 1 \\
\hline $\begin{array}{r}\text { Ribes gracile Iichx. } \\
\text { Eeguminosae }\end{array}$ & * & 200 & 0 & 13.5 \\
\hline $\begin{array}{c}\text { Gymnocladus dioica (I.) Woch. } \\
\text { Robinia Pseudo-Acacia I. } \\
\text { Caragana aborescens Lam. } \\
\text { Rhamnaceae }\end{array}$ & $\begin{array}{r}* \\
6 \\
14\end{array}$ & $\begin{array}{r}12 \\
6 \\
10\end{array}$ & $\begin{array}{l}0 \\
32 \\
9.5\end{array}$ & $\begin{array}{l}46 \\
25 \\
81\end{array}$ \\
\hline Rhamnus cathartica I. & $*$ & 21 & 0 & 56 \\
\hline
\end{tabular}

The following list of species comprises those frow which no gemination was secured from plantings of either green or mature seeds.

Iiliaceae

Polygonatum biflorum (Walt) Bll.

Betulaceae

Ostrya virginiana (will) K. Koch 

Urticaceae

Celtis occidentalis

$\underline{\text { Rosaceae }}$

Rosa rugosa Thunb.

$\underline{\text { Rutaceae }}$

Zanthoxylum americanum Mill. Ptelea trifoliata I.

Aceraceae

Acer saccharum Marsh.

Oleaceae

Fraxinus americana I.

Physocarpus opulifolius (I.) Maxim 

Tables Nos. II-IV bring out some of the same points shown by Table No. I; that is, that a large number of species will not germinate immediately after maturity and also that the species in a single order show more or less the same characteristics in regard to the time and percentage of germination. These tables probably also furnish an explanation why no germination was recorded for so many species used during the first season's work. It will be noted that only eighteen species out of forty-eight showing germination were able to germinate immediately after maturity, while twenty-seven were able to grow only after an interval of eight or ten months. During this resting interval they were subjected to the influence of freezing and undoubtedly had its effect, but evidently these species must have an extended rest period or some signs of growth would have been noticeable before spring.

Four species showed a capacity for germination in the fall. It is entirely possible that these species may require some definite temperature; that is, a temperature lower than summer heat before they can germinate. Since such a temperature is obtained only during the spring and autumn, may furnish an explanation why no growth was noticed during the summer season.

It is quite clearly shown that green or immature seeds, at least from woody plants, do not germinate nearly so freely or so readily as mature seeds of the same species. In Table No. $\nabla$ the germination of the imnature seeds is compared directly with the germination of mature seeds. Although plantings of 

air dry immature seeds were made no results were secured from them. Not enough species were used to obtain conclusive results, but green seeds seem to show a longer dormant period lower

and a percentage of germination than mature seeds of the same species .

\section{Work During the Winter of 1912-13}

\section{(A.) Seeds of Woody Plants. The principal part of}

the studies carried on during the winter of 1912-13 was confined to a smaller number of species but the seeds of each were treated in several different ways to test their powers of germination. A review of the tables previously given shows, in a general way, that seeds of woody plants possess the longer dormant period and Serminate a lower percentage than herbaceous species. With the beliof that woody seeds would present some interesting problems, practically all the seeds used during the remainder of the rork were from woody species.

In addition to merely planting the seeds of woody plants in the usual way, some of them were treated by etherizing to find if the rest period could be broken and germination hastened.

The seeds were gathered late in the fall of 1912 and thor oughly dried. They were then stored in card-board boxes on shelves in a basement room where the atmosphere would become neither too hot nor too dry. One planting of each species was made immedately upon collecting, and another about one month 

later. At the time of the second planting, another sample was soaked in tap water for three hours and then etherized for twelve hours before planting. Still another sample of ary seeds was etherized for the twenty-four hours just preceding planting. During the exposure to the influence of ether, the seeds were placed under a bell jar, a sufficient quantity of liquid ether inserted under the jar to allow 1 c.c. of ether for every 25 liters of air space, and the jar sealed to a glass plate by means of vaseline. The temperature usually ranged between $22^{\circ} \mathrm{C}$ and $25^{\circ} \mathrm{C}$.

All plantings were made in a sand bed in the greenhouse, the treated seeds being planted immediately upon removal from the ether fumes. The sand bed was kent thoroughly moist by frequent sprinkling and the greenhouse held at as uniform a temperature and humidity as possible.

Another series of experiments was begun December 17, 191\%/. by stratifying and freezing some seed from each species. Whese were placed between folds of cheese-cloth and buried in a box of sand. They were left exposed to the varying conditions of out-door temperature until rebruaty 7, 1913, when they were brought inside. One sample of each species was planted immediately while another sample was etherized for twelve hours, and another for twenty-four hours immediately previous to planting. These plantirgs were all made in the sand bed under conditions very similar to the previous plantings of the same snecies. 

The results secured from the work with woody seeds are given in Tables Nos. VI-VIII. 

Table No. VI

Effects of Various Treatments Designed to Break the

Dormant or Rest Period of Toody Plants.

*io geraination up to liay 1, 1913.

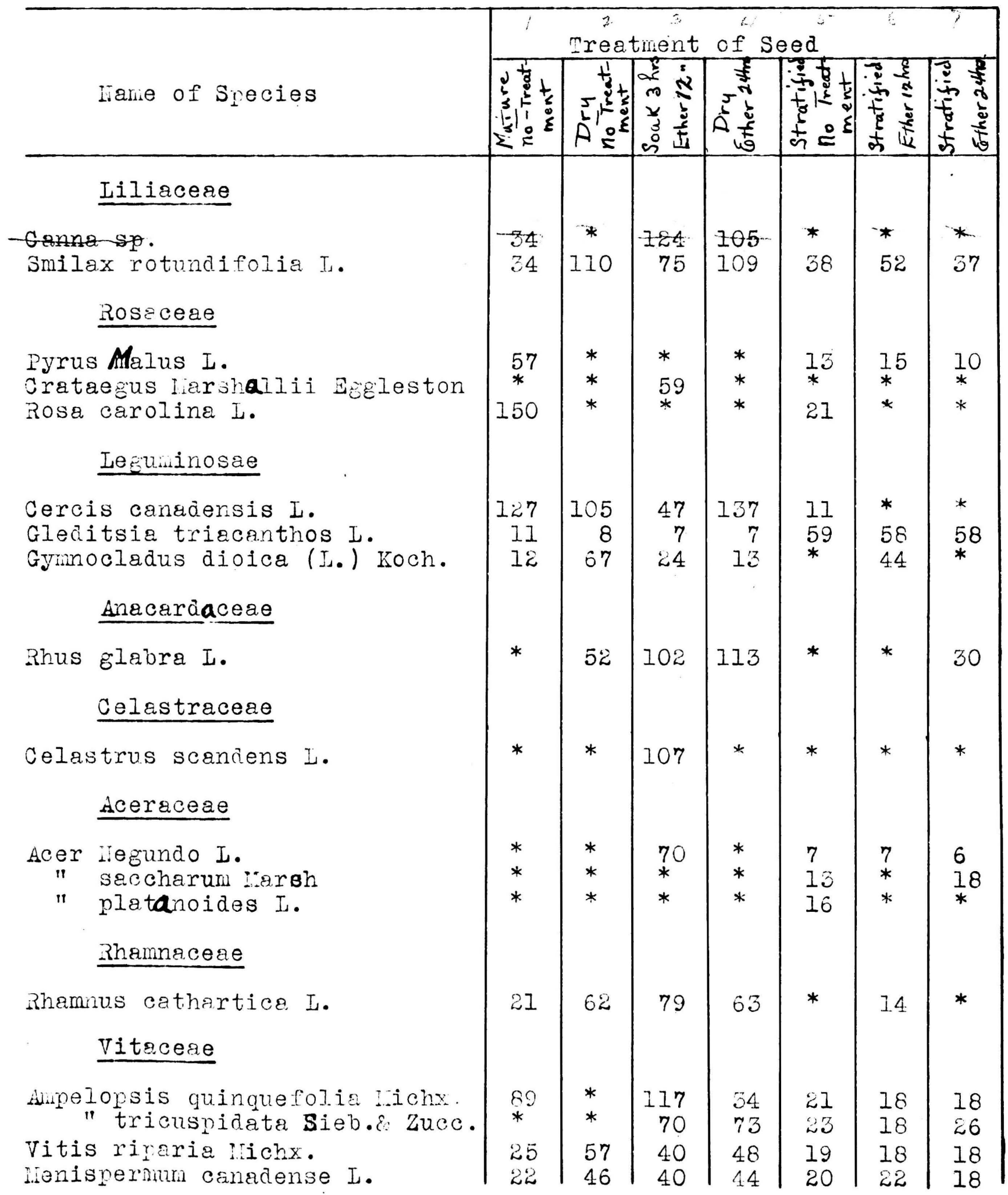





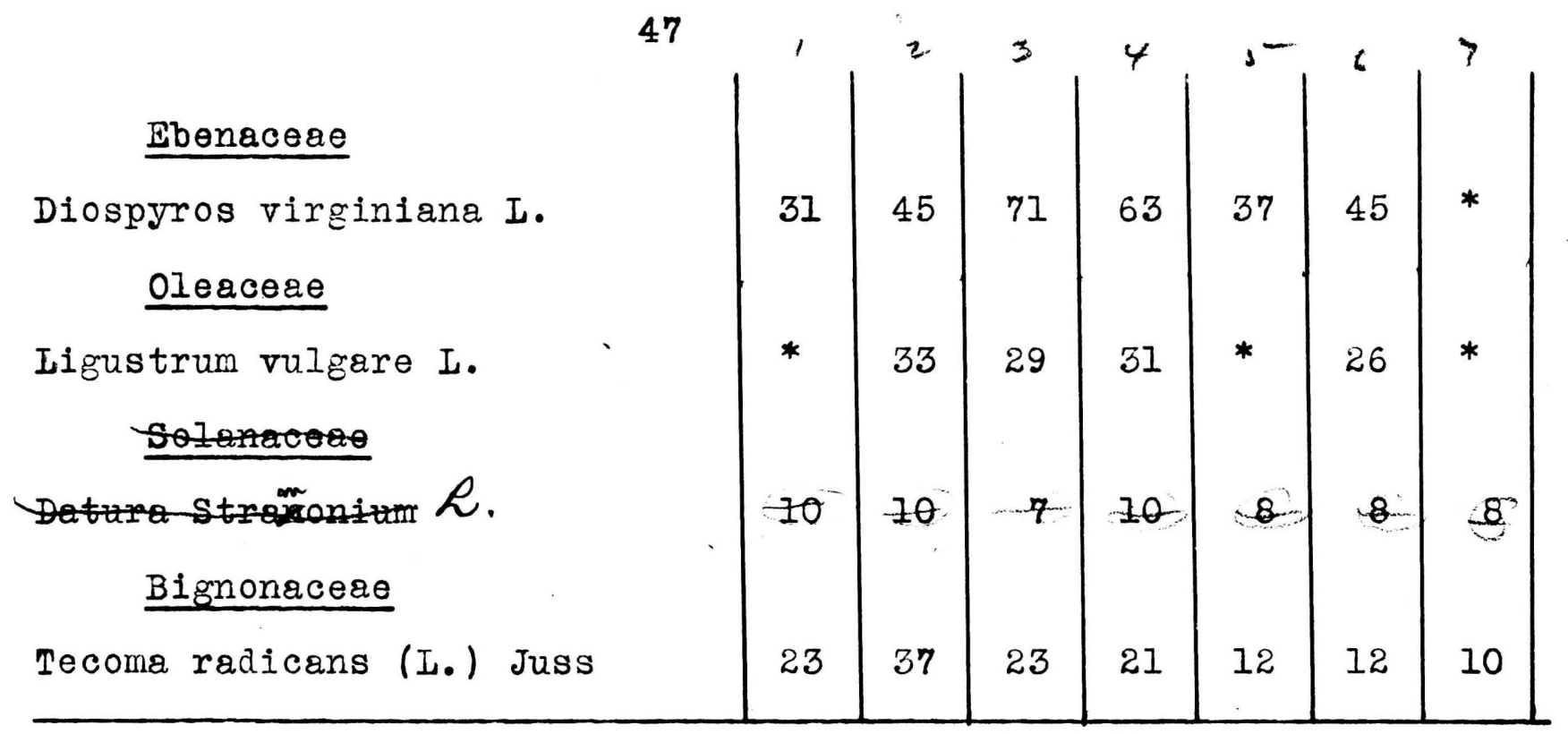



Table iro. VII

Effects of Various Treatments on Percent of Germination of Woody Seeds.

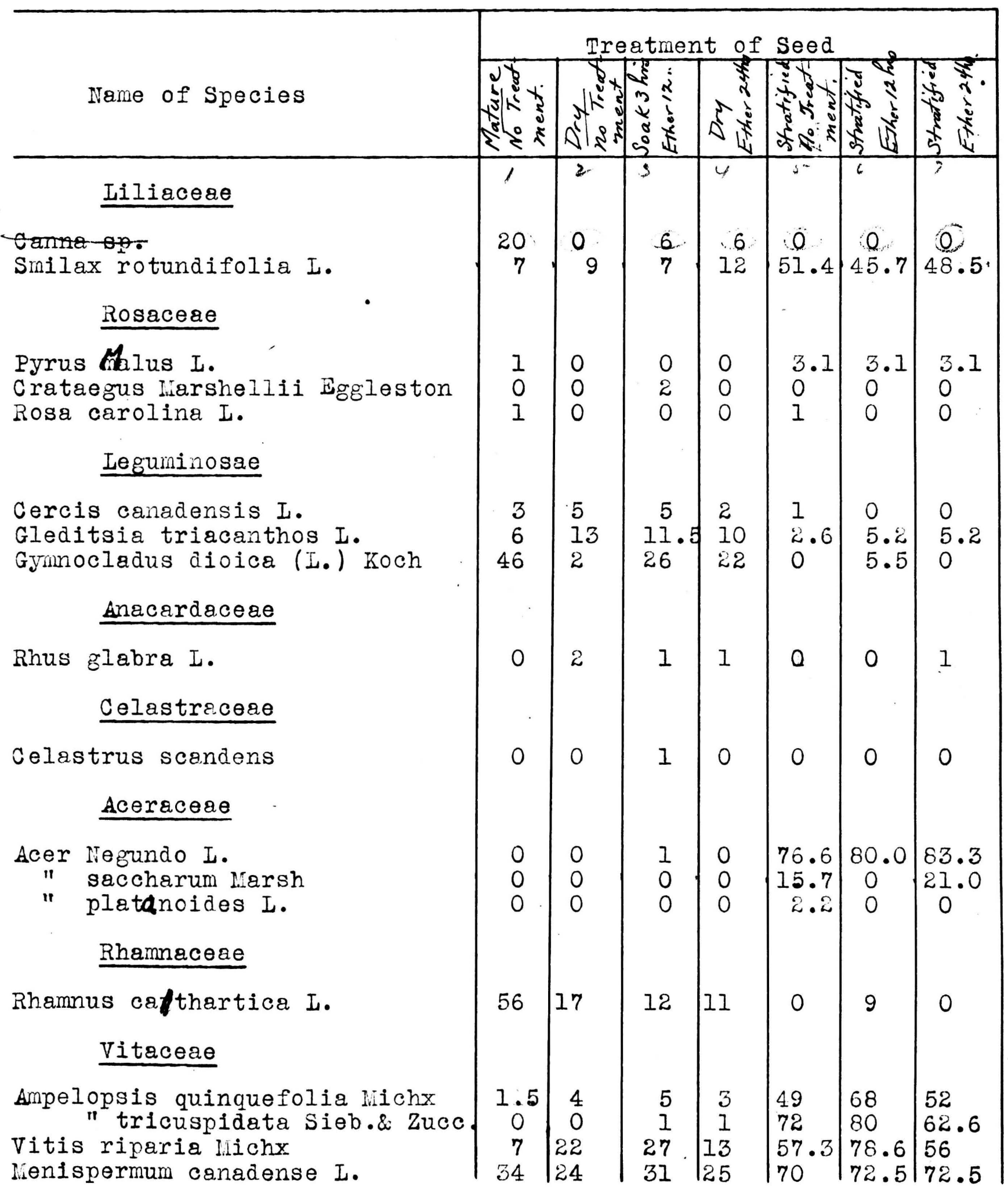





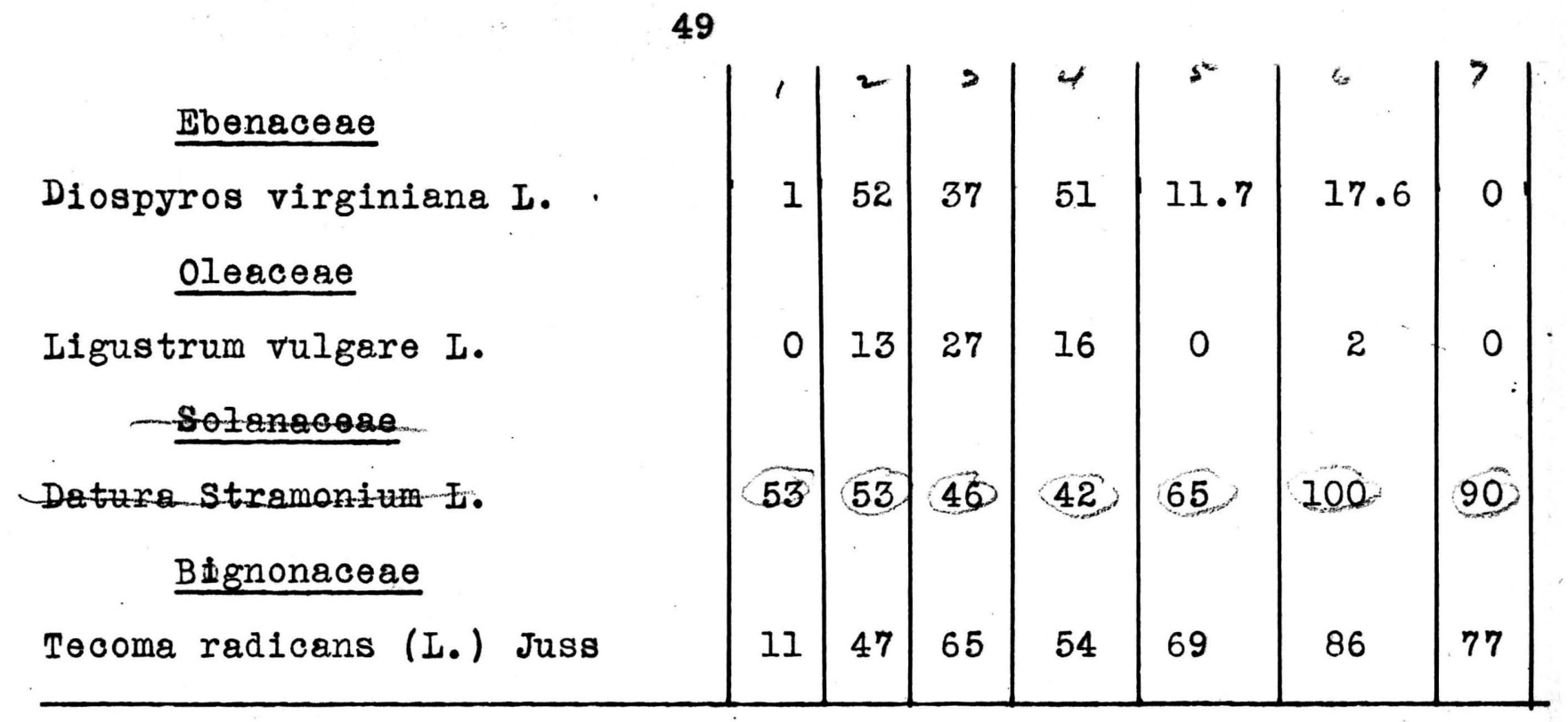



Table No. VIII

Sumiary of Tables Nos. VI - VII.

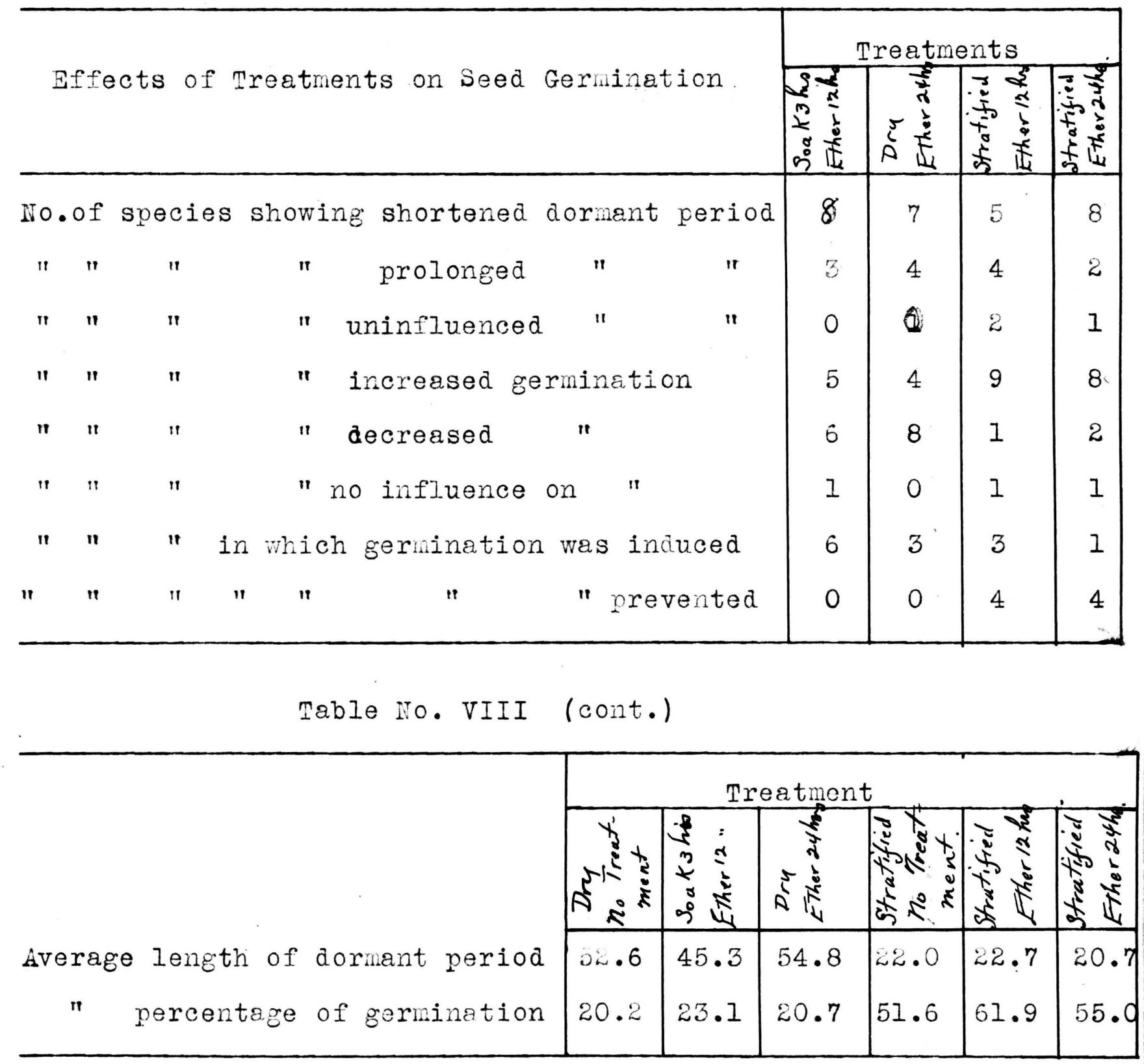



The following list of species used during the winter

of 1912-13 gave no germination under any of the treatments:

Betulacere

Ostrya virginiana I. Carpinus caroliniana I.

$\underline{\text { Rosaceae }}$

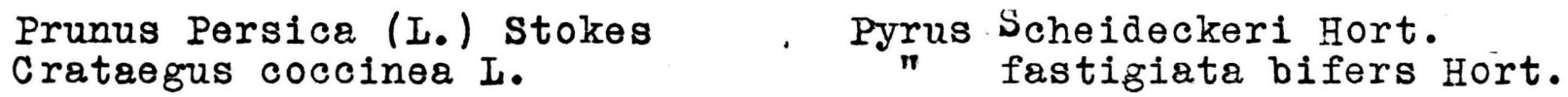

Leguminosae

Robinia Pseudo-Acacia I.

Rutaceae

Ptelea trifoliata I.

Celastraceae

Evonymus atropurpureus Jacq.

Cornaceae

Cornus asperifolia Michx.

Caprifoliacere

Symphoricarpos vulgaris Michx 

The results of the various treatments on the dormant period and the germination of seeds of woody species may be briefly summarlzed as follows:

With the unstratified seeds, the twelve hour exposure of soaked seeds to the influence of ether shortened the dormant period in nine species out of twelve. The average decrease was 7.3 days. Etherization induced germination in six species where the check planting refused to germinate but in no case was germination prevented. In six species out of twelve, however, the percentage of germination was decreased by this treatment but the average of all percentages shows an increase of $3.4 \%$ in favor of etherization.

The twenty-four hour exposure of dry unstratified seeds to ether fumes showed a shortening of the rest period in seven out of twelve species and a slight average decrease in the percentage of germination. Germination was induced in the species and prevented in none.

Stratified seeds etherized twelve hours gave a decrease in the length of the dormant period in some cases and an increase in others. However, the percentage of germination was very markedly increased, the average increase being 10.3\%. Germination was induced in three species and prevented in four.

The twenty-four hour exposure of stratified seeds to ether gave a decrease in the dormant period in eight cases out of eleven, and gave an average increased germination of $3.4 \%$. Germination was prevented in four species and induced in only one. 

The general conclusions to be drawn from this winter's work are: Stratified seeds germinate much more readily and also a higher percentage than the unstratified ones. The effect of the ether is much more marked on stratified than on unstratified seeds. The general tendency of the etherization seems to be toward reducing the dormant period and increasing the germination but different species respond to this treatment differently. The twelve hour treatment seems to be more effective than the twenty-four hour dose, both in reducing the dormant period and Increasing the germination, although here again different species vary considerably. In several cases the twenty-four hour exposure was apparently too long, for, although the percentage of germination was still increased above the check, yet it was lower than from the twelve hour treatment

(B) Seeds of Vegetables---It was seen early in the winter that only a comparatively low percentage of the woody seeds would germinate, and hence work was taken up with vegetable seeds. The seeds used were those of coimon vegetables which had been purchased previously from a commercial seed house and kept in ordinary storage.

The treatments used were (1) Etherization for twelve or twenty-four hour periods; (3)

(2) Freezing for twenty-four hours; Soaking for three or six hours; and combination of two or more of these treatments. Whenever the etherization was used it was the last treatment preceding planting. The amount of ether and the method of etherizing employed were the same as 



\section{4}

those used in the earlier work. The freezing was done with a salt and ice mixture, the temperature being kept at from -5 to $-10^{\circ} \mathrm{C}$. for twenty-four hours. The soaking was done in tap water at room temperature.

All gernination tests in this series of experiments were carried out between sheets of filter paper in wooden plates. These plates were kept in an enclosed space in the greenhouse at a temperature of approximately $22^{\circ} \mathrm{C}$. although at times the temperature varied considerably from this.

The data taken show the total germination of each sample at the end of each day for one week after the seeds were placed under conditions favorable for growth, and also the final grand total germination. These data are given in the following tables. 

Table No. IX

Effects of Various Treatments on the Germination of Zea Mays I.

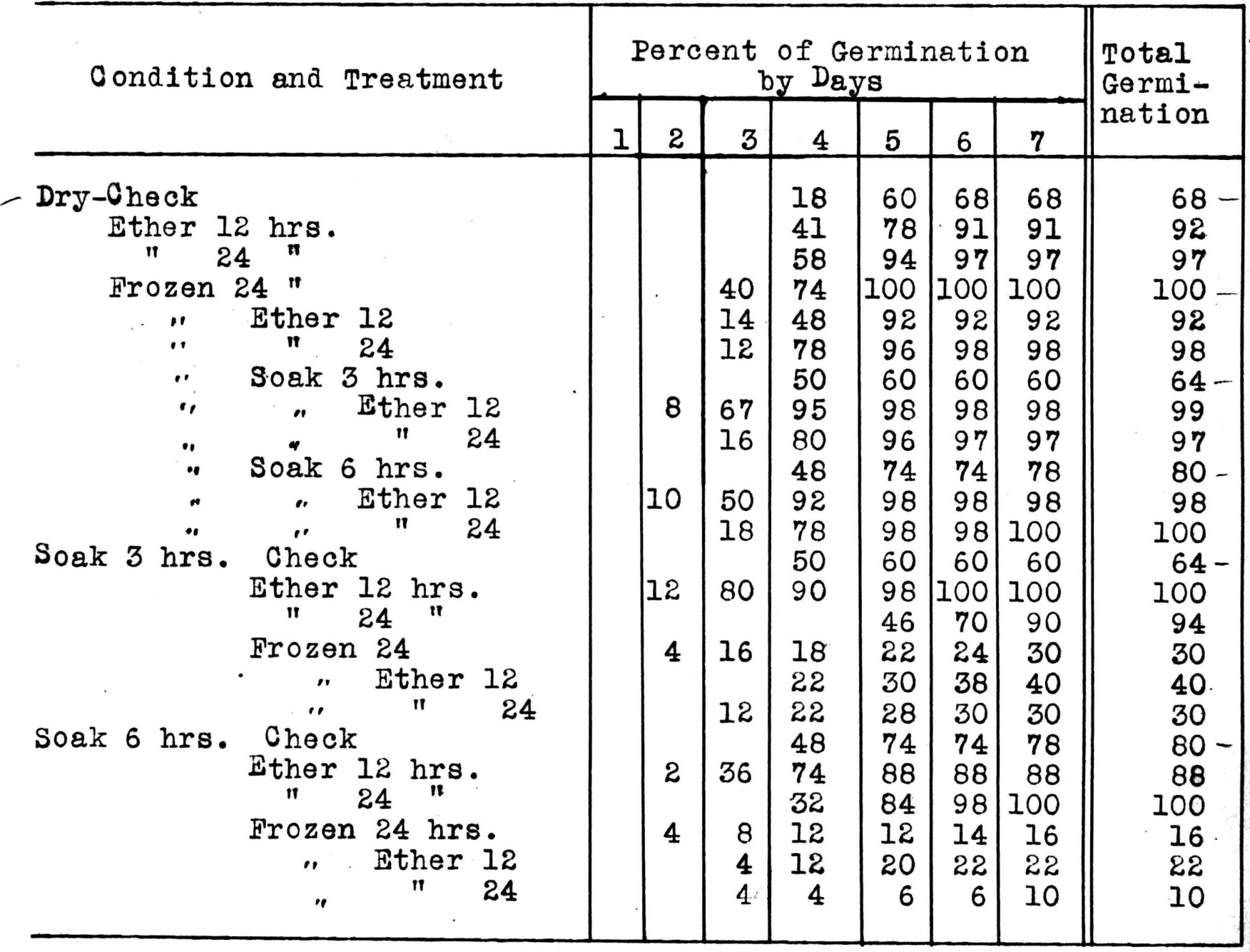





\section{6}

Table No. X

Effects of Various Treatments on the Germination of

Phaseolus lunatus I. var. Nacrocarpus, Benth.

\begin{tabular}{|c|c|c|c|c|c|c|c|c|}
\hline \multirow[t]{2}{*}{ Condition \& Treatment } & \multicolumn{7}{|c|}{$\begin{array}{c}\text { Percent of Germination } \\
\text { by Days }\end{array}$} & \multirow{2}{*}{$\begin{array}{l}\text { Total } \\
\text { Germina- } \\
\text { tion }\end{array}$} \\
\hline & 1 & 2 & 3 & 4 & 5 & 6 & 7 & \\
\hline 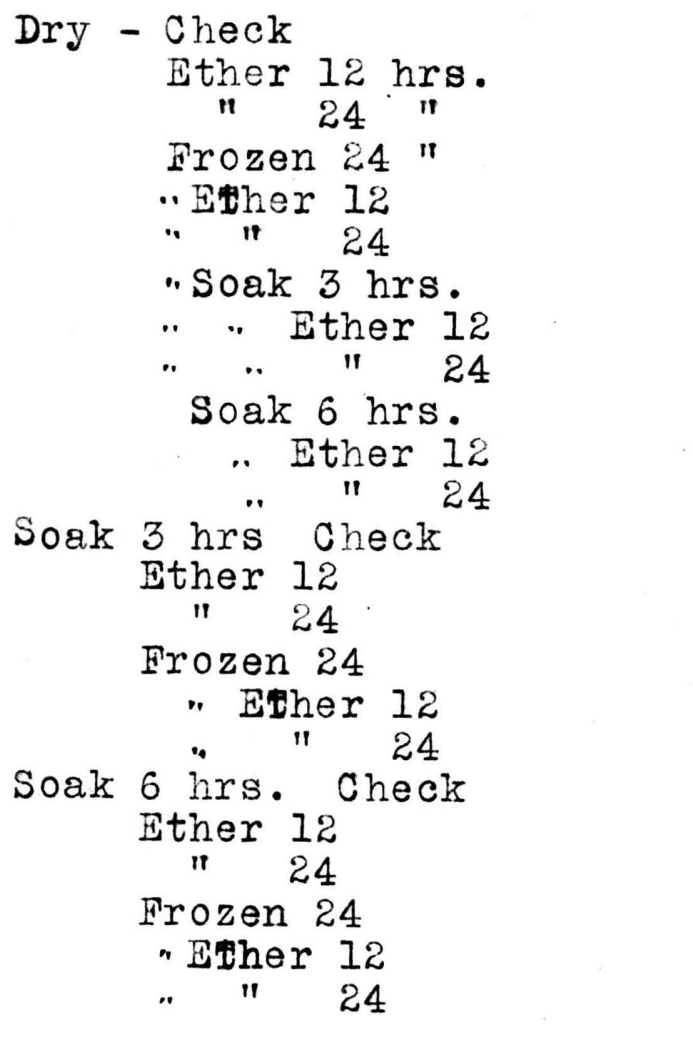 & $\begin{array}{l}12 \\
2\end{array}$ & $\begin{array}{r}10 \\
6 \\
20 \\
24 \\
4 \\
\\
8 \\
3 \\
2\end{array}$ & $\begin{array}{r}4 \\
19 \\
25 \\
10 \\
12 \\
12 \\
24 \\
14 \\
18 \\
28 \\
38 \\
20 \\
\\
25 \\
25 \\
4 \\
\\
2 \\
12 \\
20 \\
12 \\
8 \\
2\end{array}$ & $\begin{array}{l}18 \\
39 \\
52 \\
14 \\
28 \\
22 \\
40 \\
36 \\
36 \\
54 \\
52 \\
36 \\
44 \\
45 \\
49 \\
22 \\
12 \\
14 \\
40 \\
32 \\
44 \\
14 \\
4 \\
12\end{array}$ & $\begin{array}{l}38 \\
53 \\
58 \\
22 \\
32 \\
42 \\
48 \\
58 \\
50 \\
58 \\
56 \\
56 \\
52 \\
64 \\
55 \\
24 \\
24 \\
24 \\
54 \\
44 \\
54 \\
20 \\
20 \\
16\end{array}$ & $\begin{array}{l}42 \\
54 \\
62 \\
22 \\
34 \\
56 \\
48 \\
62 \\
62 \\
62 \\
56 \\
66 \\
56 \\
69 \\
59 \\
30 \\
54 \\
36 \\
56 \\
56 \\
58 \\
22 \\
28 \\
20\end{array}$ & $\begin{array}{l}54 \\
55 \\
66 \\
22 \\
40 \\
58 \\
50 \\
70 \\
72 \\
62 \\
58 \\
78 \\
62 \\
71 \\
63 \\
38 \\
38 \\
46 \\
66 \\
66 \\
60 \\
24 \\
40 \\
24\end{array}$ & $\begin{array}{l}84 \\
71 \\
75 \\
42 \backslash 4 \\
60 \\
84 \\
887 \\
82 \\
909 \\
70 \\
74 \\
96 \\
78 \\
95 \\
82 \\
50 \\
4017 \\
54 \\
82 \\
86 \\
86 \\
26 q^{2} \\
466^{\circ} \\
30\end{array}$ \\
\hline
\end{tabular}



Table No. XI

Effects of Various Treatments on the Germination of

Phaseolus vulgaris I.

\begin{tabular}{|c|c|c|c|c|c|c|c|}
\hline \multirow[t]{2}{*}{ Condition and Treatment } & \multicolumn{6}{|c|}{$\begin{array}{c}\text { Percent of Germination } \\
\text { by Days }\end{array}$} & \multirow{2}{*}{$\begin{array}{l}\text { Total } \\
\text { Germina- } \\
\text { tion }\end{array}$} \\
\hline & 2 & 3 & 4 & 5 & 6 & 7 & \\
\hline 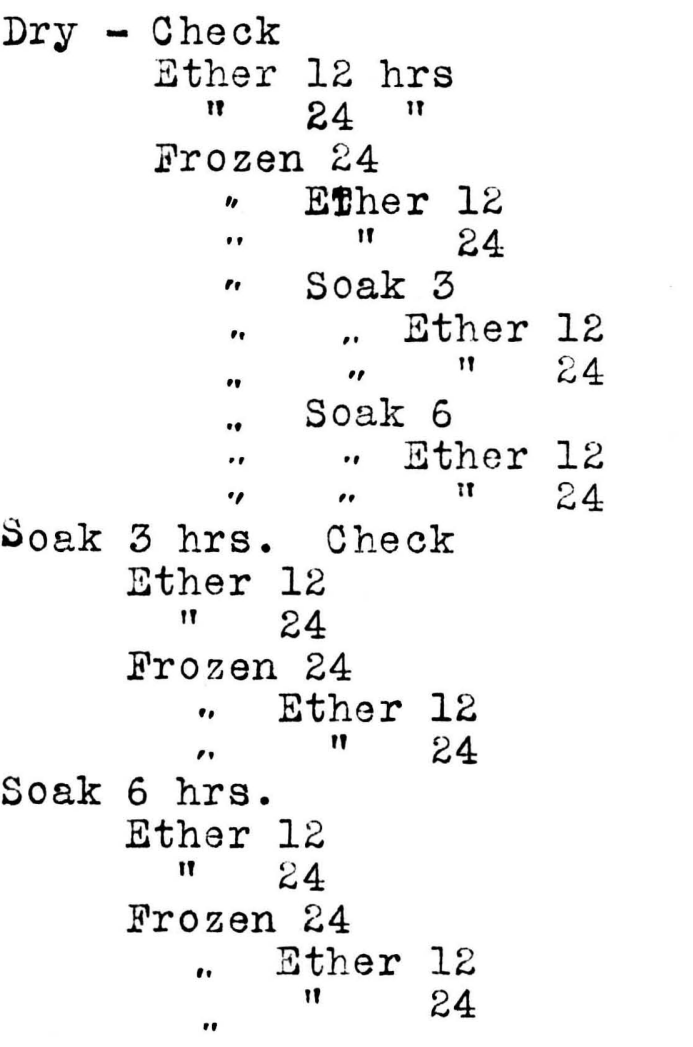 & 2 & $\begin{array}{l}2 \\
2\end{array}$ & $\begin{array}{r}4 \\
4 \\
4 \\
8 \\
\\
6 \\
4 \\
\\
8 \\
4 \\
12 \\
2 \\
2 \\
6 \\
6 \\
4 \\
2\end{array}$ & $\begin{array}{r}2 \\
2 \\
3 \\
4 \\
2 \\
2 \\
4 \\
8 \\
8 \\
12 \\
4 \\
2 \\
10 \\
7 \\
2 \\
8 \\
6 \\
14 \\
8 \\
2 \\
6 \\
10 \\
10 \\
4\end{array}$ & $\begin{array}{r}2 \\
4 \\
8 \\
8 \\
2 \\
2 \\
6 \\
12 \\
10 \\
14 \\
6 \\
10 \\
10 \\
12 \\
9 \\
8 \\
16 \\
16 \\
12 \\
6 \\
6 \\
14 \\
14 \\
6\end{array}$ & $\begin{array}{r}6 \\
4 \\
8 \\
8 \\
6 \\
2 \\
6 \\
24 \\
10 \\
16 \\
8 \\
10 \\
10 \\
13 \\
10 \\
8 \\
18 \\
22 \\
12 \\
12 \\
8 \\
14 \\
14 \\
10\end{array}$ & $\begin{array}{r}10 \\
4 \\
11 \\
8 \\
6 \\
6 \\
6 \\
26 \\
12 \\
18 \\
12 \\
12 \\
12 \\
15 \\
11 \\
8 \\
18 \\
22 \\
16 \\
12 \\
12 \\
16 \\
14 \\
10\end{array}$ \\
\hline
\end{tabular}



Table No. XII

Effects of Various Treatments on the Germination of Citrullus valgaris Schrad.

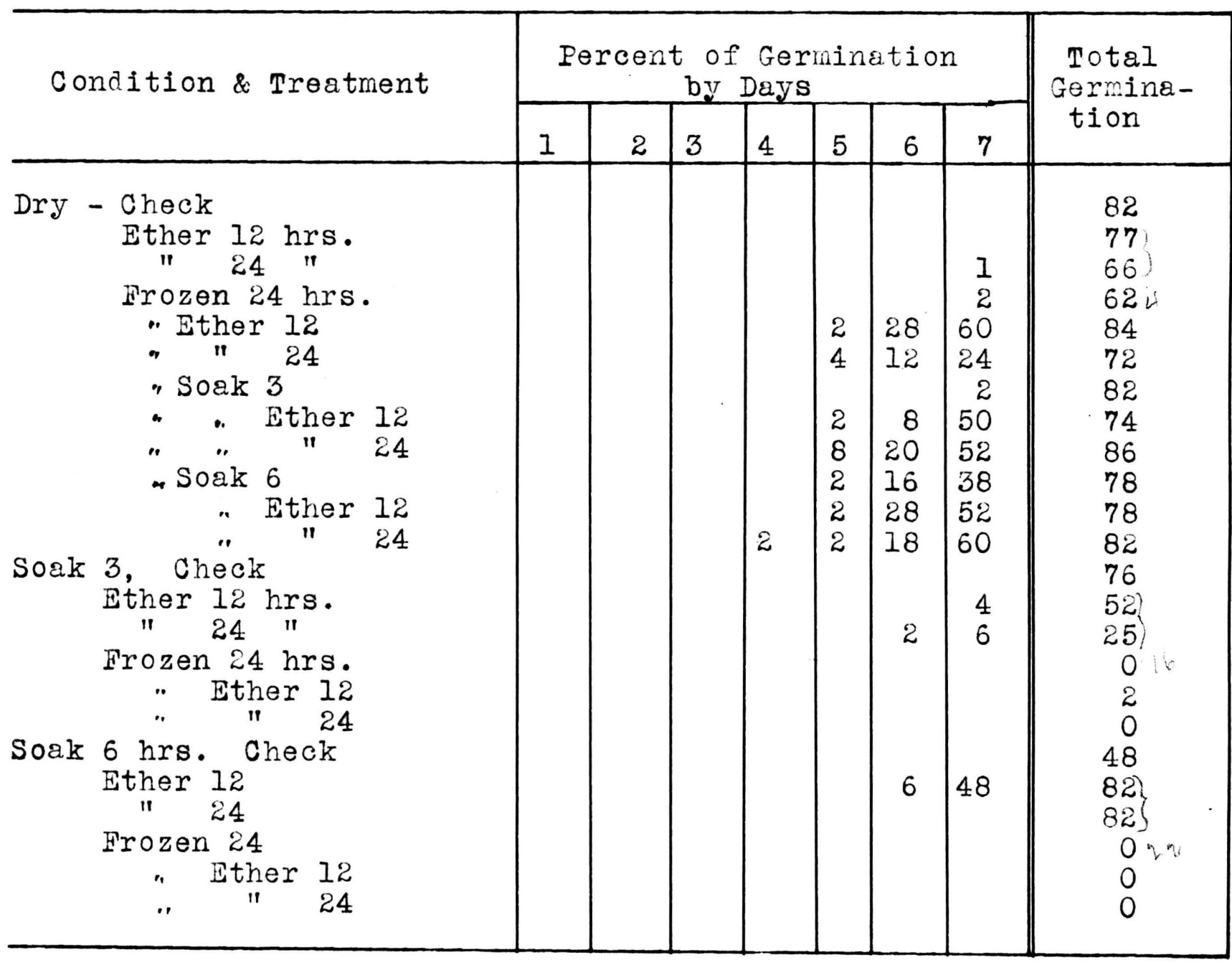





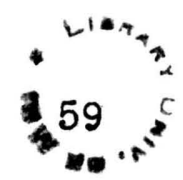

Table No. XIII

Effects of Various Treatments on the Germination of

Cucurbita maxima Duchesne.

\begin{tabular}{|c|c|c|c|c|c|c|c|c|}
\hline \multirow[t]{2}{*}{ Condition \& Treatment } & \multicolumn{7}{|c|}{$\begin{array}{c}\text { Percent of Germination } \\
\text { by Days }\end{array}$} & \multirow{2}{*}{$\begin{array}{l}\text { Total } \\
\text { Germina- } \\
\text { tion }\end{array}$} \\
\hline & 1 & 2 & 3 & 4 & 5 & 6 & 7 & \\
\hline 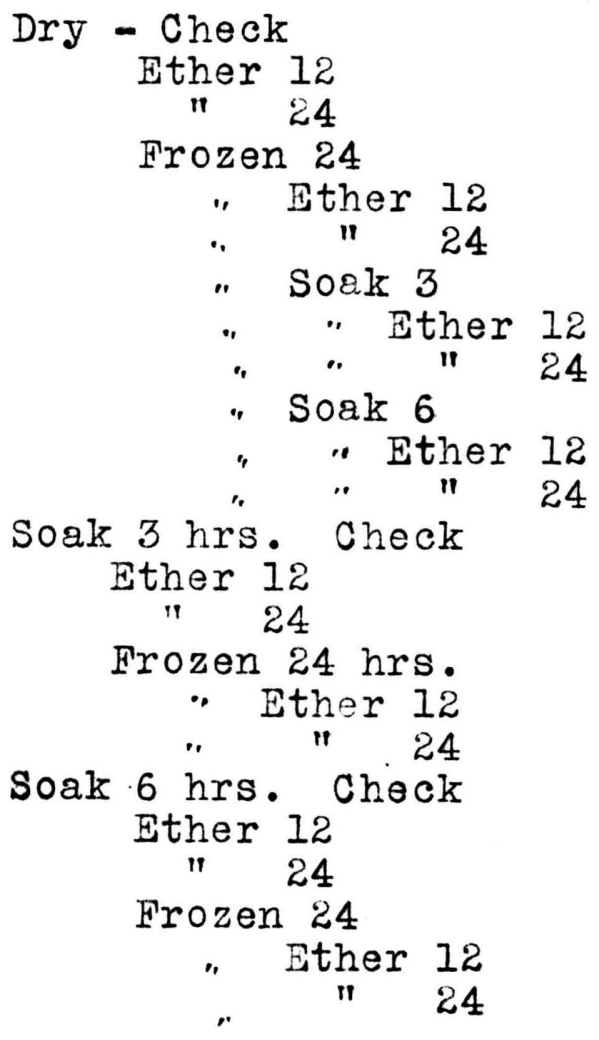 & & 2 & $\begin{array}{r}5 \\
10 \\
4 \\
10 \\
2\end{array}$ & $\begin{array}{r}4 \\
4 \\
6 \\
10 \\
4 \\
20 \\
20 \\
22 \\
6 \\
18 \\
\\
20 \\
27 \\
16 \\
14 \\
24 \\
6 \\
6 \\
4 \\
8 \\
10\end{array}$ & $\begin{array}{l}12 \\
20 \\
11 \\
20 \\
30 \\
30 \\
14 \\
38 \\
48 \\
38 \\
32 \\
38 \\
4 \\
47 \\
44 \\
28 \\
36 \\
30 \\
28 \\
12 \\
10 \\
16 \\
18\end{array}$ & $\begin{array}{l}16 \\
29 \\
19 \\
26 \\
50 \\
50 \\
28 \\
52 \\
66 \\
56 \\
54 \\
50 \\
8 \\
64 \\
49 \\
36 \\
36 \\
36 \\
12 \\
54 \\
22 \\
14 \\
20 \\
18\end{array}$ & $\begin{array}{l}28 \\
29 \\
28 \\
46 \\
64 \\
70 \\
54 \\
52 \\
70 \\
62 \\
68 \\
52 \\
22 \\
66 \\
54 \\
38 \\
38 \\
40 \\
22 \\
64 \\
34 \\
14 \\
20 \\
20\end{array}$ & $\begin{array}{l}40 \\
62 \\
53 \\
68 \\
66 \\
74 \\
72 \\
54 \\
76 \\
74 \\
74 \\
58 \\
88 \\
96 \\
77 \\
40 \\
54 \\
42 \\
60 \\
66 \\
66 \\
14 \\
24 \\
22\end{array}$ \\
\hline
\end{tabular}



Table No. XIV

Effects of Various Treatments on the Germination of Spinacia oleracea $\mathrm{I}$.

\begin{tabular}{|c|c|c|c|c|c|c|c|c|}
\hline \multirow[t]{2}{*}{ Condition \& Treatment } & \multicolumn{7}{|c|}{$\begin{array}{c}\text { Percent of Germination } \\
\text { by Days }\end{array}$} & \multirow{2}{*}{$\begin{array}{l}\text { Total } \\
\text { Germina- } \\
\text { tion }\end{array}$} \\
\hline & 1 & 2 & 3 & 4 & 5 & 6 & 7 & \\
\hline 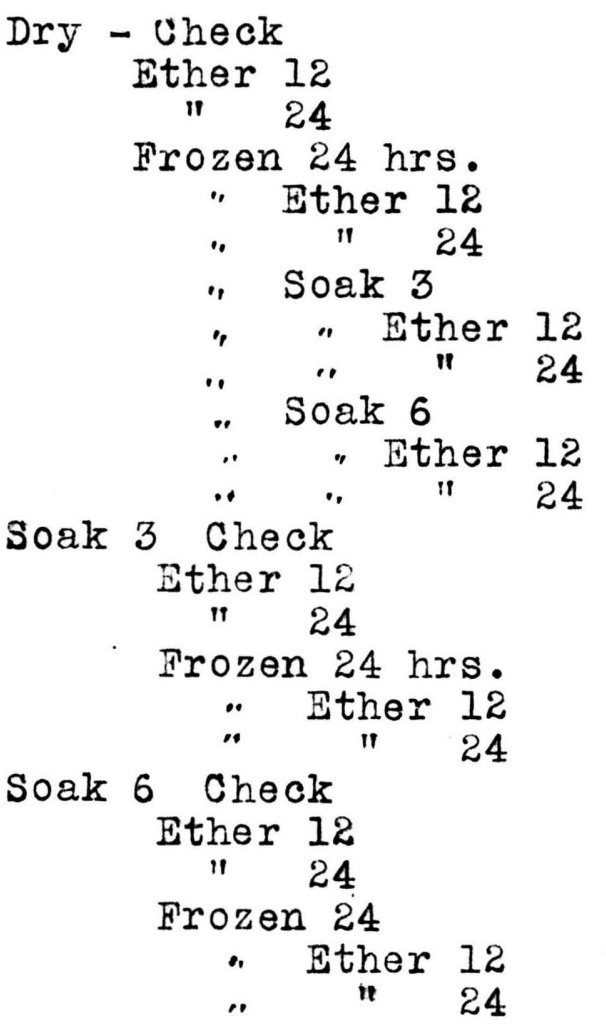 & $\begin{array}{l}11 \\
13\end{array}$ & $\begin{array}{r}2 \\
2 \\
\\
8 \\
2 \\
24^{2} \\
33 \\
10 \\
4 \\
22\end{array}$ & $\begin{array}{r}6 \\
17 \\
23 \\
2 \\
12 \\
18 \\
6 \\
10 \\
24 \\
10 \\
20 \\
24 \\
24 \\
50 \\
49 \\
4 \\
14 \\
8 \\
4 \\
38 \\
18 \\
6 \\
16 \\
4\end{array}$ & $\begin{array}{l}6 \\
29 \\
43 \\
20 \\
44 \\
44 \\
22 \\
50 \\
50 \\
20 \\
56 \\
42 \\
26 \\
60 \\
68 \\
10 \\
36 \\
24 \\
14 \\
58 \\
36 \\
10 \\
34 \\
12\end{array}$ & $\begin{array}{l}22 \\
39 \\
51 \\
48 \\
66 \\
66 \\
54 \\
60 \\
58 \\
42 \\
66 \\
48 \\
54 \\
68 \\
71 \\
12 \\
46 \\
40 \\
36 \\
66 \\
54 \\
16 \\
34 \\
28\end{array}$ & $\begin{array}{l}46 \\
54 \\
51 \\
66 \\
70 \\
66 \\
62 \\
64 \\
62 \\
44 \\
74 \\
54 \\
66 \\
74 \\
77 \\
12 \\
48 \\
40 \\
46 \\
70 \\
70 \\
16 \\
34 \\
34\end{array}$ & $\begin{array}{l}58 \\
54 \\
56 \\
66 \\
72 \\
70 \\
64 \\
72 \\
62 \\
50 \\
74 \\
58 \\
74 \\
74 \\
79 \\
14 \\
48 \\
50 \\
60 \\
74 \\
80 \\
18 \\
46 \\
34\end{array}$ & $\begin{array}{l}88 \\
74 \\
69 \\
76 \\
90 \\
82 \\
66 \\
78 \\
74 \\
60 \\
80 \\
66 \\
84 \\
95 \\
89 \\
18 \\
54 \\
66 \\
72 \\
86 \\
86 \\
22 \\
56 \\
52\end{array}$ \\
\hline
\end{tabular}



Table No. XV

Effect of Various Treatments on the Germination of Raphanus sativus I.

\begin{tabular}{|c|c|c|c|c|c|c|c|c|}
\hline \multirow[t]{2}{*}{ Condition \& Treatment } & \multicolumn{7}{|c|}{$\begin{array}{c}\text { Percent of Germination } \\
\text { by Days }\end{array}$} & \multirow{2}{*}{$\begin{array}{l}\text { Total } \\
\text { Germina- } \\
\text { tion }\end{array}$} \\
\hline & $I$ & 2 & 3 & 4 & 5 & 6 & 7 & \\
\hline 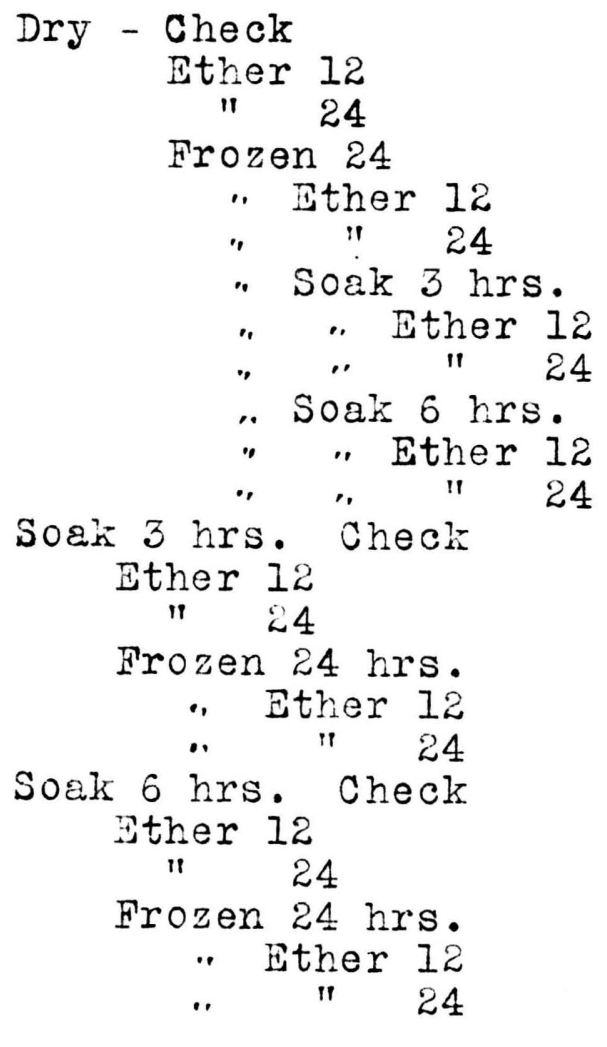 & $\begin{array}{l}16 \\
12 \\
20 \\
16 \\
50 \\
42\end{array}$ & $\begin{array}{c}62 \\
40 \\
4 \\
64 \\
58 \\
66 \\
20 \\
68 \\
66 \\
28 \\
72 \\
72 \\
42 \\
60 \\
24 \\
28 \\
48 \\
42 \\
84 \\
36 \\
30 \\
38\end{array}$ & $\begin{array}{l}70 \\
58 \\
38 \\
68 \\
68 \\
76 \\
48 \\
68 \\
74 \\
60 \\
78 \\
78 \\
78 \\
86 \\
74 \\
38 \\
78 \\
14 \\
76 \\
84 \\
58 \\
38 \\
70 \\
18\end{array}$ & $\begin{array}{l}80 \\
74 \\
44 \\
76 \\
74 \\
80 \\
76 \\
74 \\
76 \\
76 \\
78 \\
84 \\
84 \\
90 \\
80 \\
38 \\
80 \\
20 \\
82 \\
84 \\
70 \\
40 \\
78 \\
28\end{array}$ & $\begin{array}{l}80 \\
76 \\
48 \\
76 \\
82 \\
84 \\
76 \\
74 \\
76 \\
76 \\
78 \\
84 \\
84 \\
90 \\
82 \\
42 \\
86 \\
30 \\
88 \\
84 \\
72 \\
46 \\
80 \\
34\end{array}$ & $\begin{array}{l}80 \\
78 \\
50 \\
76 \\
82 \\
84 \\
84 \\
76 \\
82 \\
82 \\
80 \\
84 \\
84 \\
92 \\
82 \\
42 \\
88 \\
30 \\
90 \\
84 \\
72 \\
46 \\
82 \\
38\end{array}$ & $\begin{array}{l}80 \\
82 \\
50 \\
76 \\
82 \\
86 \\
86 \\
76 \\
82- \\
84 \\
80 \\
84 \\
88 \\
92 \\
84 \\
42 \\
88 \\
30 \\
92 \\
88 \\
78 \\
46 \\
82 \\
38\end{array}$ & $\begin{array}{l}80 \\
82 \\
56 \\
76 \\
86 \\
86 \\
88 \\
80 \\
82 \\
86 \\
80 \\
88 \\
88 \\
92 \\
86 \\
44 \\
90 \\
44 \\
96 \\
88 \\
78 \\
50 \\
88 \\
44\end{array}$ \\
\hline
\end{tabular}



Table INo. XVI

Effects of Various Treatments on the Germination of

Hibiscus esculentus $I$.

\begin{tabular}{|c|c|c|c|c|c|c|c|c|}
\hline \multirow[t]{2}{*}{ Condition \& Treatment } & \multicolumn{7}{|c|}{$\begin{array}{c}\text { Percent of Germination } \\
\text { by Days }\end{array}$} & \multirow{2}{*}{$\begin{array}{l}\text { Total } \\
\text { Germina- } \\
\text { tion. }\end{array}$} \\
\hline & 1 & 2 & 3 & 4 & 5 & 6 & 7 & \\
\hline 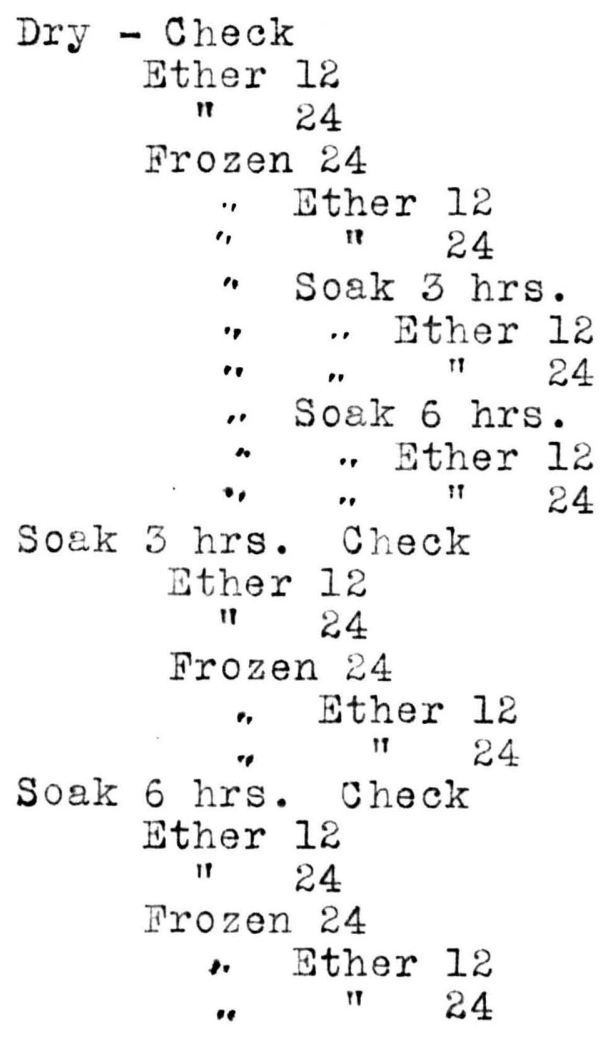 & 2 & $\begin{array}{r}3 \\
3 \\
4 \\
10\end{array}$ & $\begin{array}{r}9 \\
27 \\
6 \\
14 \\
4 \\
10 \\
\\
8 \\
8 \\
4\end{array}$ & $\begin{array}{r}2 \\
6 \\
27 \\
37 \\
10 \\
22 \\
12 \\
18 \\
6 \\
8 \\
16 \\
8\end{array}$ & $\begin{array}{r}4 \\
20 \\
17 \\
12 \\
10 \\
10 \\
2 \\
6 \\
4 \\
4 \\
10 \\
\\
27 \\
38 \\
12 \\
22 \\
12 \\
20 \\
8 \\
8 \\
26 \\
8\end{array}$ & $\begin{array}{r}10 \\
21 \\
17 \\
12 \\
10 \\
10 \\
2 \\
6 \\
6 \\
6 \\
10 \\
\\
27 \\
38 \\
12 \\
22 \\
14 \\
4 \\
22 \\
12 \\
8 \\
26 \\
8\end{array}$ & $\begin{array}{r}10 \\
21 \\
17 \\
12 \\
10 \\
10 \\
2 \\
6 \\
8 \\
\\
10 \\
10 \\
\\
27 \\
38 \\
12 \\
22 \\
14 \\
6 \\
26 \\
16 \\
8 \\
26 \\
8\end{array}$ & $\begin{array}{c}18 \\
25 \\
20 \\
18 \\
18 \\
12 \\
2 \\
6 \\
10 \\
2 \\
12 \\
16 \\
4 \\
29 \\
41 \\
14 \\
24 \\
14 \\
6 \\
26 \\
20 \\
10 \\
26 \\
10\end{array}$ \\
\hline
\end{tabular}



Table INo. XVII

Effects of Various Treatments on the Germination of Allium Cepa I.

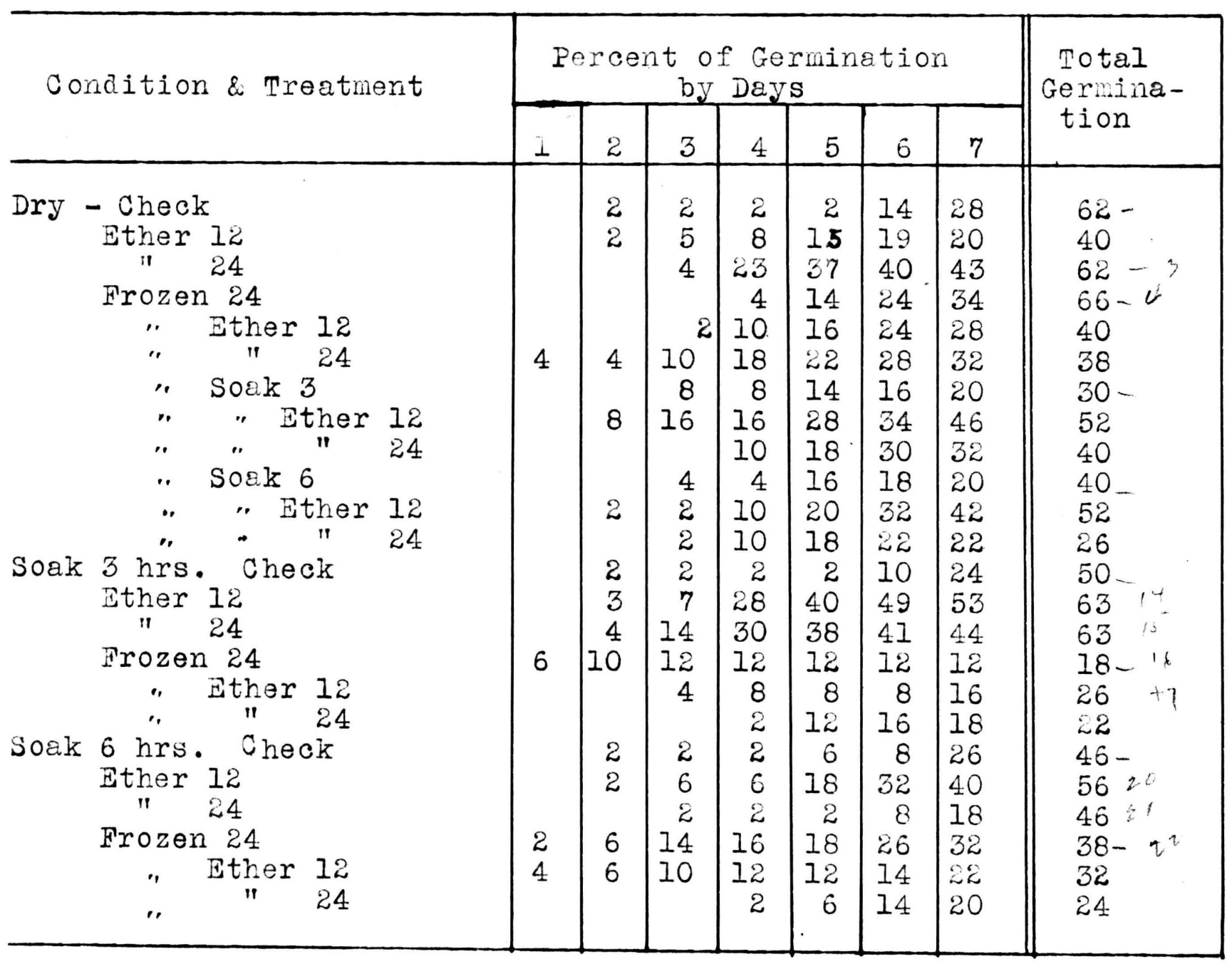



Table No. XVIII

Summary of Tables Nos. IX to XVII

\begin{tabular}{|c|c|c|c|c|c|c|c|c|c|c|}
\hline \multirow{2}{*}{$\begin{array}{l}\text { Condition and } \\
\text { Treatment }\end{array}$} & \multicolumn{9}{|c|}{ Table No. } & \multirow{2}{*}{$\begin{array}{l}\text { Aver } \\
\text { ege } \\
\%\end{array}$} \\
\hline & $I X$ & $X$ & $X I$ & XII & XIII & $\mathrm{XIV}$ & XV & $X V I$ & XVII & \\
\hline \multirow{2}{*}{$\begin{array}{l}\text { Dry Check } \\
\text { Ether 12 }\end{array}$} & 68 & 84 & 10 & .82 & 40 & 88 & 80 & 18 & 62 & I. 59 \\
\hline & 92 & 71 & 4 & 77 & 62 & 74 & 82 & 25 & 40 & 58.5 \\
\hline \multirow{2}{*}{$\begin{array}{l}\text { Frozen } 24 \\
\text { Ether } 12\end{array}$} & 97 & 75 & 11 & 66 & 53 & 69 & 56 & 20 & 62 & 56.5 \\
\hline & 100 & 42 & 8 & 62 & 68 & 76 & 76 & 18 & $\overline{66}$ & 57.3 \\
\hline \multirow{2}{*}{ 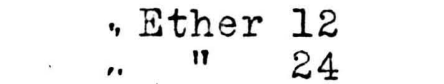 } & 92 & 60 & 6 & 84 & 66 & 90 & 86 & 18 & 40 & 60.2 \\
\hline & 98 & 84 & 6 & 72 & 74 & 82 & 86 & 12 & 38 & 61.3 \\
\hline "Soak $3^{24}$ & 64 & 88 & 6 & 82 & 72 & 66 & 88 & 2 & 30 & 55.3 \\
\hline - Ether 12 & 99 & 82 & 26 & 74 & 54 & 78 & 80 & 6 & 52 & 61.2 \\
\hline \multirow{2}{*}{ "Soak 6} & 97 & 90 & 12 & 86 & 76 & 74 & 82 & 10 & 40 & 63.0 \\
\hline & 80 & 70 & 18 & 78 & 74 & 60 & 86 & 2 & $\overline{40}$ & 56.4 \\
\hline ". Ether 12 & 98 & 74 & 12 & 78 & 74 & 80 & 80 & 12 & 52 & 62.2 \\
\hline \multirow{2}{*}{ Soak $\ddot{3}$ hrs. Check } & 100 & 96 & 12 & 82 & 58 & 66 & 88 & 16 & 26 & 60.4 \\
\hline & $\begin{array}{r}64 \\
100\end{array}$ & $\begin{array}{l}78 \\
95\end{array}$ & $\begin{array}{l}12 \\
15\end{array}$ & $\begin{array}{l}76 \\
52\end{array}$ & $\begin{array}{l}88 \\
96\end{array}$ & $\begin{array}{l}84 \\
95\end{array}$ & $\begin{array}{l}88 \\
82\end{array}$ & $\begin{array}{r}4 \\
20\end{array}$ & 50 & 60.4 \\
\hline $\begin{array}{c}\text { Soak } 3 \text { hrs. Check } \\
\text { Ether } 12 \\
" 124\end{array}$ & $\begin{array}{r}100 \\
94\end{array}$ & 82 & 11 & $\begin{array}{l}52 \\
25\end{array}$ & $\begin{array}{l}90 \\
77\end{array}$ & $\begin{array}{l}95 \\
89\end{array}$ & 86 & 41 & $\begin{array}{r}00 \\
63\end{array}$ & 63.1 \\
\hline \multirow{2}{*}{$\begin{array}{l}\text { Frozen } 24 \\
\text { "Ether } 12\end{array}$} & 30 & 50 & 8 & 0 & 40 & 18 & 44 & 14 & $\overline{18}$ & 24.6 \\
\hline & 40 & 40 & 18 & 2 & 54 & 54 & 90 & 24 & 26 & 38.6 \\
\hline \multirow{4}{*}{ 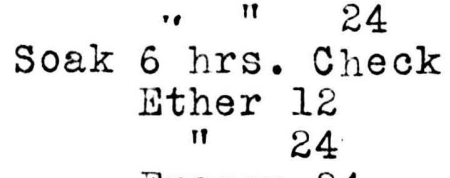 } & 30 & 54 & 22 & 0 & 42 & 66 & 44 & 14 & 22 & 32.6 \\
\hline & 80 & 82 & 16 & 48 & 60 & 72 & 96 & o &.$\overline{46}$ & 56.2 \\
\hline & 88 & 86 & 12 & 82 & 66 & 86 & 88 & 26 & $=56$ & 65.5 \\
\hline & 100 & 86 & 12 & 82 & 66 & 86 & 78 & 20 & $=46$ & 64.0 \\
\hline & 16 & 26 & 16 & 0 & 14 & 22 & 50 & 10 & $=\overline{36}$ & 21.3 \\
\hline "Ether 12 & 22 & 46 & 14 & 0 & 24 & 56 & 88 & 26 & $=32$ & $34 \cdot 2$ \\
\hline " $" \quad 24$ & 10 & 30 & 10 & 0 & 22 & 52 & 44 & 10 & 24 & 22.4 \\
\hline \multicolumn{11}{|l|}{ Average of all } \\
\hline $\begin{array}{l}\text { Check Plantings } \\
\text { Average of all } 12\end{array}$ & 62.7 & 65.0 & 11.7 & 53.5 & 57.0 & 60.7 & 73.5 & 9.2 & 37.5 & 47.8 \\
\hline \multirow{2}{*}{$\begin{array}{l}\text { hr. Treatments } \\
\text { Average of all } 24 \\
\text { hr. Treatments }\end{array}$} & 78.8 & 69.2 & 13.3 & 56.1 & 62.0 & 76.6 & 85.7 & 20.7 & 44.8 & 56.3 \\
\hline & 78.2 & 74.6 & 12.0 & 51.6 & 58.5 & 73.0 & 70.2 & 17.8 & 37.6 & 52.6 \\
\hline & & & & & & & & & & W \\
\hline
\end{tabular}



An analysis of the ten precending tables shows that etherization of old dry seeds has but little effect on their germination and, in some cases, a detrimental effect on the total germination is observed.

Freezing dry seeds apparently has but little effect on either the time or the percentage of germination. A twelve hour exposure to ether after the freezing process, however, will quite materially hasten the germination of some species but in others no difference occurs. The twenty-four hour exposure is not so effective in stimulating germination as the shorter treatment. Seeds which have been frozen and then soaked for three hours will generally have a hastened growth, but if the soaked seeds are etherized for twelve hours before planting a marked difference is observed. Quick germination has been materially stimulated and a higher germination occurs. The twenty-four hour treatment gives practically the same results as the shorter. exposure.

Soaking the frozen dry seeds for six hours has nearly the same effect as soaking for three hours. However, the twelve hour exposure of such seeds to ether gave a higher average total germination than did the ones which were treated for twenty-four hours. This may perhaps be explained on the theory that growth had already begun in seeds which had been soaked six hours and that a twenty-four hour ether exposure was harmful to active protoplasm.

Soaking dry seeds for three hours has a tendency to produce quickened germination but a twelve-hour exposure to ether 

in addition to the soaking, will hasten it still more in many cases. Hastened germination was secured in seven cases out of nine in which the last treatment was used. A twenty-four hour period of etherization also seems to hasten germination but the percentage of germination is not so materially increased as with the preceding treatment.

Seeds which had been soaked for three hours and then frozen showed hastened germination in a few cases but with practically every species a much lower total germination was secured. The ether treatments apparently stimulated a highe $\dot{r}$ percentage of germination and in a majority of cases the twelve hour exposure induced quicker growth.

Seeds soaked six hours do not show much advantage in either the time or amount of germination over those soaked only three hours. However, etherization of such seeds tends to hasten the germination and also raise the percentage of germination. The twelve hour treatment is more effective than the longer exposure.

Seeds soaked six hours and then frozen are badly damaged by such treatment but etherization, especially for the twelve-hour period, seems to have the power of causing a greatly increased percentage of germination. The twenty-four hour treatment seems to be of very little advantage in this case.

4 summary of all the treatments in every table shows that the average percentage of germinations for all check plantings was 47.8\%; for AII plantings after a twelve-hour ether treat-. ment 56.3\%, and for the twenty-four hour etherization 

52.6\%. The check planting germinated in twenty-nine cases on the first day on which germination was recorded for that series (that is, the check, 12 hour and 24 hour ether treatments), the twelve-hour exposure in forty-seven cases and the twenty-four hour treatment in only thirty cases. The twelve-hour treatment, when compared with the check, gave a hastened germination in thirty-six cases and retarded it in only eighteen while the twenty-four hour exposure hastened it in twenty-five cases and retarded it in twenty-four. 



\section{SUIIIARY}

\section{First year's work.}

First:--Seeds have a rest period or period when they will not germinate even when placed under ideal growing conditions.

Second:--The rest period of seeds seems to begin as soon as they are ripe or mature.

Third:--Seeds that were air-dried for one month and then planted, germinated 4.4 days quicker than those which were planted immediately after ripening. Fourth:--Air-dried seeds also gave a higher percentage $(6.6 \%)$ of germination than the ones planted just after maturity.

Fifth:--Just how long the rest period of seeds lasts was not determined but it probably varies greatly with the different species.

Sixth:--The various species of a single order seem to behave more or less alike in regard to the time and percentage of germination.

Second season's work.

First:--The rest period of the seed of some species is very much more extended than that of others. Second:--Many species, which do not show germination immediately after maturity, will gerninate if given sufficient time. (That is, they probably pass through their rest period before sprouting). 

Third:-Those species which did not germinate until spring may have been affected by freezing. Fourth:--A few species which did not grow in summer, did germinate in the autumn.

Fifth:--Green or immature seeds, at least of woody plants, usually do not germinate as readily as mature seeds of the same species.

Work during Winter of 1912-13.

(a) Seods of Woody Plants.

First:--A twelve hour ether treatment of dry seeds hastened germination on the average 7.3 days and increased the germination $3.4 \%$.

Second:--A similar twenty-four hour exposure to ether fumes hastened germination in a majority of cases but exerted only a small influence on the per cent.

Third:--Ether treatment seems to induce germination in some species.

Fourth:--Stratified seeds of practically all the species used germinated more quickly and gave a higher percentage.

Fifth:--The effect of ether on stratified seeds is much greater than it is on dry seeds.

Sixth:--Rthenseemingly prevented germination in some species.

Seventh:--A twenty-four hour exposure to ether does not seem to be as effective as a twelve-hour expos- 

ure for stimulating germination.

Eighth:--Different species react differently to the various treatments used.

(b) Seeds of Vegetables.

First:--Etherization stimulates early germination of seeds but its effect varies with the different species.

Second:--Soaked or moist seed are more readily affected by ether than dry ones.

Third:--A twelve hour exposure to an ether atmosphere seems to be more effective in proomoting hastened and increased germination than the longer treatment.

Fourth:--Rapid freezing does not greatly affect dry seeds but it seriously damages the germinating power of many species if the seeds have been previously soaked.

Fifth:--Etherization of frozen seeds seems to increase the total percentage of germination and in some cases hastens germination. 



\section{General Conclusions.}

1. Seeds do have a rest period, evidenced by the fact that many species which will not grow immediately after maturity, will germinate after they have been dried, subjected to various treatments, or allowed to lie in the ground all winter.

2. The length and intensity of the rest period varies with different species but all the species of a single order seem to be more or less similar in these respects.

3. Seeds which have been air-dried for one month will germinate on the average more quickly and with a higher percentage than the freshly gathered mature seeds, but it was not determined whether this was due to the desiccation or to some other factor or factors.

4. Stratified seeds as a general rule germinate more readily and with a higher percentage than seeds not so treated.

5. Etherization tends to stimulate seeds into an early growth and it also tends to increase the percentage of total germination. Soaked or stratified seeds are more strongly affected by ether treatments than dry seeds. A twelve hour exposure to ether is more favorable for germination than the twenty-four hour exposure.

6. Not all specles respond in the same way nor to the same extent to treatinents with ether.

7. Rapid freezing more seriously affects moist or soaked seeds than dry ones. 



\section{BIBIIOGRAPHY.}

1. Arthur, J. C., Delayed Germination of Xanthium and other Paired Seeds.

Proc. Soc. Prom. Agrl. Sc., Vol. 16.

2. Beal, W. J., The Vitality of Seeds Buried in the Soil. Proc. Soc. Prom. Agrl. Sc., Vol. 31.

3. Crocker, W., Germination of the Seeds of Water Plants. Botanical Gazette, Vol. 44.

4. Fawcett, H. S., The Vitality of Weed Seeds under Different Conditions of Treatment and a Study of Their

Dormant Periods.

Proc. Iowa Acad. Sc., Vol. 15, No. 38.

5. Giglioli, I., Action of Gases and Liquids on the Vitality of Seeds.

Nature, Vol. 35.

6. Hempel, Jenny. Researches into the Effect of Etherization on plant Metabolism.

(Reprint from "Det. Kongelige Danske

Videnskabernes Selskab Skrifter, 7. Rakke, Naturvidensk, og Nathem. Afd. VI, 6"). Copenhagen 1911.

7. Howard, W. I., An Experimental Study of the Rest. Period of Plants: The Winter Rest. Mo. Exp. Sta. Research Bul. 1 .

8. Jost, I., Plant Physiology (Trans. by R. J. H. Gibson) Oxford 1907. 

9. Kinney, A. S., Electro-Germination.

liass. Hatch $\operatorname{Exp}$. Sta. Bul. 43.

10. Lewis, C. I., Forcing Bulbs by lieans of Ether.

Cornell Countryman 3, No. 8, 1906.

1l. Iove, H. H., \& Leighty, U. H., Germination of Seed as Affected by Sulfuric Acid Treatment. Cornell Exp. Sta. Bul. 312.

12. Pammel, I. H., \& King, Charlotte 1., Delayed Germination. Proc. Iowa. Acad. Sc. Vol. 15, No. 45.

13. Pfeffer, W., Plant Physiology Vol. II. (Trans. by L.J.Ewart) Oxford 1903.

14. Pickering, S. U., Studies in Seed Germination and Plant Growth. 9 th Report Woburn $\mathbf{E}_{x p}$. Fruit Farm.

15. Read, J. W., Some Factors Influencing the Germination of Corn. Thesis, University of lissouri, 1908.

16. Shull, C. A., The Oxygen Minimum and the Germination of zanthium seeds.

Botanical Gazette, Vol. 52 .

17. Stone, G. E., \& Smith, R. E., Influence of Chemical Solutions Upon the Germination of Seeds. Mass. Hatch Bxp. Sta. Report 1901.

18. Taubenhaus, J., Ether and the Germination of Seeds. Cornell Countryman 5, No. 6, 1908.

19. Thornber, J. J., Seed Germination.

Arizona Exp. Sta. Report 1904.

20. Townsend, C. O., Effect of Ether Upon the Germination of Seeds and Spores.

Botanical Gazette, Vol. 27. 

21. U. S. Department of Agriculture, Experiment Station Record, numerous references.

22. Waldron, I. R., Weed Studies.

Ni. D. $\operatorname{Exp}$. Sta. Bul. 62 .

23. Waugh, H. A., The Artificial Use of Enzymes in Germination. Vermont Exp. Sta. Report 1898. 







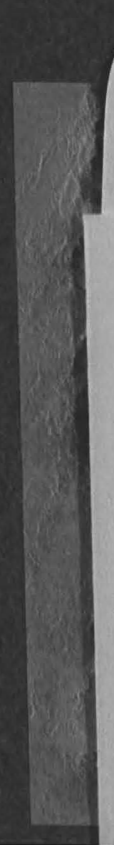




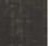

